
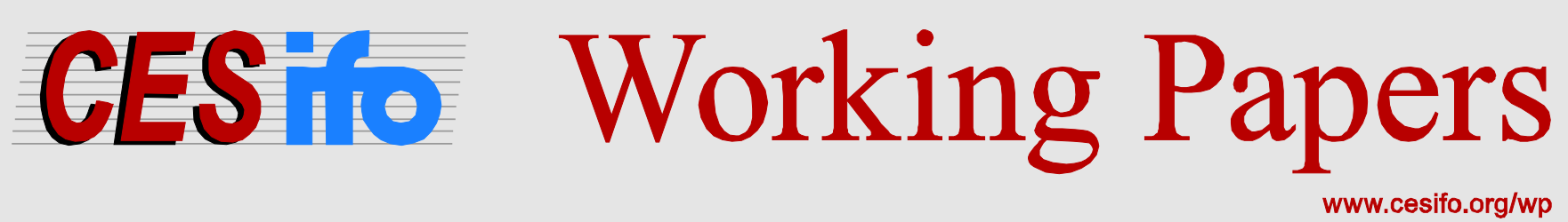

\title{
The Gender Gap in Entrepreneurship: Not Just a Matter of Personality
}

\author{
Marco Caliendo \\ Frank Fossen \\ Alexander Kritikos \\ Miriam Wetter
}

CESIFO WORKING PAPER NO. 4803

CATEGORY 4: LABOUR MARKETS

MAY 2014
An electronic version of the paper may be downloaded
- from the SSRN website: Www.SSRN.com
- from the RePEc website: $\quad$ www.RePEc.org
- from the CESifo website: www.CESifo-group.org/wp




\title{
The Gender Gap in Entrepreneurship: Not Just a Matter of Personality
}

\begin{abstract}
Why do entrepreneurship rates differ so markedly by gender? Using data from a large, representative German household panel, we investigate to what extent personality traits, human capital, and the employment history influence the start-up decision and can explain the gender gap in entrepreneurship. Applying a decomposition analysis, we observe that the higher risk aversion among women explains a large share of the entrepreneurial gender gap. We also find an education effect contributing to the gender difference. In contrast, the Big Five model and the current employment state have effects in the opposite direction, meaning that the gender gap in entrepreneurial entry would be even larger if women had the same scores and the same employment status as men.
\end{abstract}

JEL-Code: L260, J160, D810, J240, M130.

Keywords: entrepreneurship, gender gap, personality, decomposition analysis.

\author{
Marco Caliendo \\ University of Potsdam \\ Chair of Empirical Economics \\ Germany - 14482 Potsdam
}

caliendo@empwifo.uni-potsdam.de

\author{
Frank Fossen \\ Free University Berlin \\ Berlin / Germany \\ frank.fossen@fu-berlin.de
}

\author{
Miriam Wetter* \\ University of Potsdam \\ Chair of Empirical Economics \\ Germany - 14482 Potsdam \\ wetter@empwifo.uni-potsdam.de
}

${ }^{*}$ corresponding author

May 6, 2014

We would like to thank Alessandra Casarico, Maria Minniti, Paola Profeta, Maria Lucia Stefani, participants at the 2012 Academy of Management Annual Meeting (Boston, MA), the 2013 CESifo Venice Summer Institute on 'The determinants of gender gaps', and workshop participants of the 2nd Potsdam PhD Workshop in Empirical Economics for their helpful and valuable comments. 


\section{Introduction}

It is an almost worldwide phenomenon that there are fewer women involved in entrepreneurial activities than men (Kelley et al., 2013). And despite this phenomenon's persistence, it remains a puzzle as to why this gap exists. Research focusing on various personality characteristics reveals that women score different from men in characteristics such as fear of failure (Wagner, 2007), risk attitudes (Caliendo et al., 2009), self-confidence (Koellinger et al., 2013) or the willingness to compete (Bönte and Piegeler, 2013). The differing scores do partly account for the gender gap, but provide only modest explanation.

We also know from previous research that other personal variables beyond personality characteristics influence entrepreneurial decision making, among them important variables such as age, the labour market status or the level of human capital (Georgellis and Wall, 2005). Although research on the gender gap is increasing, not much focuses on the question of how much of the gender gap can be attributed to a comprehensive set of personality characteristics and to socio-demographic variables.

Moreover, to better understand the gap and to identify new leads on how to close it, it is necessary to analyse the entry decision into entrepreneurial activities. Similarly to the unequal shares of men and women in the stock of the self-employed ${ }^{1}$ we find in most countries that the share of women starting a business each year is smaller than the share of men (see Global Entrepreneurship Monitor, 2005). Closing the gender gap in entrepreneurship will, however, be feasible only if the entry rates of women will become more similar to the entry rates of men. Increasing female entry rates into entrepreneurship might become a crucial policy target as entrepreneurs benefit economies through innovative activities, new job creation, increased productivity, and competition, or because they accelerate structural change. Economies with fewer females engaged in entrepreneurship have, therefore, untapped potential.

In this paper, we will turn the attention to the gap among the entries into selfemployment. Using the German Socio-Economic Panel (SOEP), a large representative

\footnotetext{
${ }^{1}$ According to the German microcensus, in Germany the number of self-employed women is about half the number of self-employed men (Piorkowsky et al., 2013).
} 
household survey of the German population, for the years 2000 to 2009, we analyse in a first step how personality and socio-demographics influence the entry decision of men and women into self-employment. Based on these findings, we conduct a non-linear decomposition analysis to assess to what extent the gender gap in the entry rates into self-employment in Germany can be attributed to personality and to other variables. In contrast to previous research the main advantage of our data set is that it contains not only information on the socio-demographic background of the respondents, but also on a broad set of personality constructs that elicit the Big Five traits and several specific personality characteristics. To the best of our knowledge information on the Big Five approach has not been used to assess the gender gap in entrepreneurship. We are the first to simultaneously analyse the effects of the Big Five factors, risk aversion, locus of control, and the ability to trust others (Caliendo et al., 2012), as well as of a variety of variables controlling for human capital, employment status, and other socio-demographic factors on the gender specific decision to enter self-employment.

Our decomposition analysis reveals several surprising results. First of all, we show that personality traits help explain the gender gap in nuanced ways. While specific characteristics, in particular risk attitudes, are able to explain a substantial amount of the gender gap, the overall influence of the Big Five personality constructs point to the opposite direction. This means that if women were endowed with the same scores in the Big Five as men, the gap would be even larger. A second set of variables partly explaining the gender gap are differences in the education level. On average, working aged women in Germany are still less educated than men and are, therefore, less inclined to start a business. Thirdly, the current employment state has a strong effect into the opposite direction: If the share of women in wage employment were as high as the male share, holding everything else constant, their entry rate into self-employment would be much smaller. Interestingly, the overall explained gap is therefore negative meaning that if women exhibited in all observable variables the same parameter values as men, the entry rate of women would be even smaller than actually observed. This underlines the potential importance of unobservable 
influences on the gender gap such as discrimination by lenders and customers ${ }^{2}$ or different gender roles that may act as invisible barriers to female entrepreneurship. The rest of the paper is organised as follows. Based on existing heuristics, in Section 2 we present the theoretical background and empirical evidence from the literature on variables influencing the occupational choice of men and women into entrepreneurial activities. In Section 3, we describe the representative panel data used in our analysis, present descriptive statistics of the data, and provide a short overview of the econometric approach. Section 4 is devoted to the presentation of the results and Section 5 concludes.

\section{Theoretical Considerations}

Why do men more often than women choose to become active in entrepreneurship? Occupational choice models assert that persons prefer entrepreneurship over wage employment or unemployment if the utility they face once entering self-employment is higher than the utility they had in their previous work status. In this section we briefly analyse in which direction specific variables, which we know from previous research to be crucial for entrepreneurial activities, influence entrepreneurial decisions. As we are particularly interested whether these determinants differ by gender, we discuss such differences where possible. ${ }^{3}$ More specifically, we will discuss the influence of human capital, of the employment status, of wealth effects, but also the influence of traits described by the Big Five Factor Model, and of the more specific personality characteristics risk preference and locus of control. ${ }^{4}$

Throughout all parts of their business, entrepreneurs need to have profound skills, good knowledge and abilities in a wide range of fields to choose the best or most efficient options amongst a wide range of services (Lazear, 2004). This holds from being innova-

\footnotetext{
${ }^{2}$ Cf. Borjas and Bronars (1989) and Fairlie (1999) in the context of African-American and white selfemployment in the US.

${ }^{3}$ The factors leading to gender differences in self-employment, but also in dependent employment, can be grouped into two broad sets. On the one hand we can observe on an individual level characteristics, preferences, traits, abilities, and attitudes, which lead to a different engagement in self-employment by gender. On the other hand, external factors and constraints might influence an individual's decision process or might even regulate the entrepreneurial possibilities (Campa et al., 2011). Our analysis will primarily concentrate on the first, the individual level.

${ }^{4}$ In the analysis, we further consider the inclination to trust others (Caliendo et al., 2012).
} 
tive to the production of a new product or service, the planning of financial investments and to representing the business to possible clients or investors. As a result, highly educated individuals are likely to have a higher propensity to enter self-employment, whereas individuals with low education levels are less likely to choose entrepreneurship. ${ }^{5}$ In this context, the distribution of education by gender has undergone a major change over the last decades. While older-aged men on average are higher educated than women, younger women have caught up. Today, even a higher share of women graduates from university in several developed economies. Nevertheless, working age women are on average still lower educated (Dustmann, 2005). Given a positive influence of education on the probability of entrepreneurial entry, Van Der Sluis et al. (2008) review the literature on the effect of education on entrepreneurship and find no significant difference of the effect between men and women. ${ }^{6}$ Therefore, the entrepreneurial gender gap might be partly explained by the gender difference in educational attainment which is still prevailing.

As to the influence of the employment status, individuals in wage employment may in general be less likely to start an own business due to the higher risk that is implied when starting a new business. Paid employees might be less affected by the macroeconomic situation or overall fluctuations in demand, while they might be inclined to trust on their regular monthly income and social insurance coverage. Related to gender differences, it is important to note that the lower labour force participation rate of women (Antecol, 2000) may play a specific role in the analysis of the gender gap in entrepreneurial entry rates. Rosti and Chelli (2005) show that in Italy, men typically enter self-employment out of wage work, while women enter out of inactivity. Georgellis and Wall (2005) argue that for women, self-employment may be a relatively close substitute for non-participation because of the flexibility it provides regarding the timing and location of work. Having a wage job increases the opportunity costs of self-employment and may therefore decrease the probability of entry, holding everything else (e.g., work experience, education, and the family situation) constant. Therefore it is important to control for the individual labour

\footnotetext{
${ }^{5}$ This holds true for most developed countries (Blanchflower, 2000).

${ }^{6}$ See also Furdas and Kohn (2010).
} 
market status prior to a potential entry into self-employment, and to investigate if the effects differ by gender.

Blanchflower and Oswald (1998) note that wealth has a high explanatory power for the decision to enter self-employment as well. For instance, persons who received an inheritance are more likely to become an entrepreneur. Women may face more binding credit constraints than men due to discrimination by lenders (Georgellis and Wall, 2005). This may partly explain why female owned businesses employ less assets on average (Rosa et al., 1996); on the other hand, women may also be more active in businesses that require less capital input. Thus, it is an empirical question if and how capital contributes to the gender gap.

Previous research (e.g. Rauch and Frese, 2007) investigates how personality traits influence the self-employment status, but little is known whether these effects differ by gender. Since distributions of personality traits vary by gender (Borghans et al., 2008), gender differences in personality are potential candidates to explain parts of the entrepreneurial gender gap, and the effect of personality traits might also be gender specific.

We first consider the Big Five Factor Model of personality (McCrae and Costa, 2008), which describes the personality by the factors openness to experience, conscientiousness, extraversion, agreeableness, and neuroticism (or, reversely, emotional stability). Persons scoring high in openness to experience tend to be creative, innovative and curious, with all three of these features being necessary for and therefore positively related with entrepreneurial activity. Extraversion describes the abilities of being assertive, of seeking leadership, and of developing social networks; characteristics which are important with regard to self-employment. Individuals scoring high in conscientiousness are achievement oriented and hard workers. Agreeable persons are forgiving, altruistic, and cooperative. A higher score in neuroticism means that a person is emotionally less stable, less selfconfident and less stress-resistant; characteristics also crucial during the start-up period of entrepreneurial activities. Zhao and Seibert (2006) report significant effects of all five factors on the probability of being an entrepreneur. Caliendo et al. (2014) find a posi- 
tive effect of extraversion and openness (and to a limited extent of emotional stability) on the entry probability into self-employment. As women score higher in openness and extraversion, ${ }^{7}$ one would expect a higher probability of entry into entrepreneurship for women than for men, based on these personality traits alone. The literature does not provide much guidance with regard to potential roles of agreeableness and neuroticism in the entrepreneurial gender gap. Last but not least, competitiveness can be seen as one component of conscientiousness. Bönte and Piegeler (2013) find that women score significantly lower in competitiveness and therefore have a lower probability of being an entrepreneur.

In addition to the Big Five factors, we also consider specific personality characteristics, such as risk aversion and locus of control, which the literature prominently identifies as relevant for entrepreneurial decisions. Self-employment involves more risk and uncertainty regarding survival of the business and monthly income than an employed position. Therefore, the level of risk aversion is deemed to play a crucial role. Individuals with a higher willingness to take risk are more likely to enter self-employment (see inter alia Cramer et al., 2002, Kan and Tsai, 2006, or Norton and Moore, 2006) and this holds true for both genders (Caliendo et al., 2009). As women are at the same time more risk-averse than men (see Croson and Gneezy, 2009, for an overview of several studies), we expect risk aversion to have explanatory power with respect to the gender gap in the transition to self-employment. ${ }^{8}$

In addition to risk preference, internal locus of control is thought to influence the entry decision into entrepreneurship (Evans and Leigthon, 1989). Believing to determine future outcomes with one's own actions, will have a positive effect on the probability to become self-employed (cf. Caliendo et al., 2014). Literature on gender differences in the context of

\footnotetext{
${ }^{7}$ Schmitt et al. (2008) and Weisberg et al. (2011) analyse the distributions of the Big Five factors by gender and find that women score significantly higher in extraversion, neuroticism, and agreeableness. The distribution of openness varies with respect to the definition.

${ }^{8}$ This expectation is supported by prior research. Verheul et al. (2012) find that differences in risk tolerance explain a part of the gender gap in the preference for self-employment. Fossen (2012) estimates a structural microeconometric model of self-employment transitions. The estimated risk aversion parameter is larger for women, and the difference is responsible for a small part of the gender gap in the entry rate into self-employment. Using individual data from the Flash Eurobarometer, Entrepreneurship 2009, Bönte and Piegeler (2013) also find evidence that a large part of the entrepreneurial gender gap can be explained by the lower risk tolerance of women.
} 
locus of control suggest that women score lower on internal and higher on external locus of control than men (Sherman et al., 1997). While no direct analysis of locus of control and entrepreneurial gender differences is available in the literature, Koellinger et al. (2013) report that fear of failure, which can be related to locus of control, plays a significant role explaining the gender gap in nascent entrepreneurship. ${ }^{9}$ We therefore expect a higher entry rate for men than for women due to the gender specific distribution of locus of control.

In summary, our expectations are that the gender gap in entrepreneurial entry may be explained by gender differences in education, employment status, capital assets, and personality as measured by the Big Five factors as well as, more specifically, risk attitude and locus of control.

\section{Data and Methodological Approach}

\subsection{Representative Survey Data}

We obtain our data from the German Socio Economic Panel (SOEP). The SOEP is a large, representative household panel survey that collects information on over 22,000 individuals in approximately 12,000 households in Germany on an annual basis. It provides comprehensive information on socio-demographics, employment history and further labour market information on the individual and household levels (cf. Wagner et al., 2007). Additionally, the SOEP includes inventories of personality characteristics (see Section 3.2).

We operationalize entrepreneurship as self-employment, with persons being defined as self-employed if they state self-employment as their primary labour activity. Entry into self-employment is defined as a shift of the employment status from wage employment, unemployment or non-participating status to self-employment between the interviews in years $t$ and $t+1$. It is worth noting that 42 percent of the men in our sample who are in their first year of self-employment already report having at least one employee, but only 21 percent of the women. For our analysis, we use the survey waves 2000-2010, although the information of the year 2010 is only used to observe whether an individual enters

\footnotetext{
${ }^{9}$ The paper is based on the Global Entrepreneurship Monitor (GEM). A nascent entrepreneur is defined as an individual who is actively participating in start-up activities.
} 
self-employment between 2009 and 2010. Furthermore, we exclude individuals working for a self-employed family member, farmers, as well as persons in civil service, the military, or still in education. We argue that these persons are more restricted in terms of their occupational choice. Although the official retirement age in Germany is 65, we only include persons aged 59 and younger in our sample, due to flexible pension schemes and early retirement decisions. The sample also only includes people who are 25 years or older, because the personality of younger persons may still be developing (see Cobb-Clark and Schurer, 2012). ${ }^{10}$

Since we analyse the decision to enter self-employment, the relevant estimation sample consists of all observations of persons currently not self-employed, a total of 60,313 personyears, without missing values in the relevant variables, including 59,609 observations not entering self-employment and 704 observations of entry into self-employment. Table A.1 in Appendix A further splits the observations by gender and employment status in $t$. The annual rate of entry into self-employment is 1.35 percent for men, and 1.01 percent for women, constituting the gender gap (the difference is significant at the 1 percentlevel). For both genders, the entry rate is higher for those currently unemployed or not participating in the labour market than for paid employees, presumably because of the higher opportunity costs of the latter. The step into self-employment may be easier than finding wage employment for persons currently not employed. This may hold, for instance, for married women after having raised children at home, especially in case of part-time selfemployment, which we count as self-employment as long as it is reported as the primary work activity.

\subsection{Personality Inventories}

As mentioned above, the SOEP includes short versions of established psychological inventories of personality characteristics in several waves. ${ }^{11}$ This allows us to analyse the

\footnotetext{
${ }^{10}$ The results are similar if only persons above 29 years of age are included in the sample.

${ }^{11}$ General tests on the validity and on the reliability of the instrument measuring the Big Five factors are provided by Lang et al. (2011, pp. 553-554). They report that the questionnaire used "is a reasonable, short instrument designed to measure the Big Five personality factors in large surveys".
} 
influence of a comprehensive set of personality traits in a large representative sample. In inventories of the Big Five, locus of control and trust constructs, the respondents are asked how much they agree with different statements about themselves (on 7-point Likert scales). Fifteen items assess the Big Five personality traits (3 items for each trait), ten items measure internal and external locus of control, and three questions elicit how much one is inclined to trust others. The personality constructs are obtained by averaging the scores from the respective items; factor analysis confirms the validity of the constructs (see Caliendo et al., 2014, for details). Risk aversion is measured in repeated survey waves by a single question about the general willingness to take risks on an 11-point scale. The wording of the single items can be found in Table A.2 in Appendix A.

Although the personality items are not included in every survey wave, literature suggests that personality traits are stable over time. Cobb-Clark and Schurer (2012, 2013) and Dohmen et al. (2007) provide evidence for the stability of personality traits and risk preferences of working-aged individuals. Hence, we use the individual information on personality provided in certain waves also in other waves. To facilitate the interpretation of the estimation results, all personality variables, except for the willingness to take risk, are mean standardised using the estimation sample of individuals not being self-employed.

In our data risk tolerance is positively correlated with openness to experience and extraversion and negatively with neuroticism and agreeableness, and as expected, the correlation between internal and external locus of control is negative. The correlations do not lead to a problem of multicollinearity amongst the regressors in the analysis; the variance inflation factors calculated after a linear regression of the self-employment indicator on all explanatory variables are all below $5 .{ }^{12}$

\subsection{Mean Gender Differences}

Table 1 shows mean characteristics of men and women, in the full estimation sample of all persons not being self-employed and for the sub-sample of individuals who we observe just

\footnotetext{
${ }^{12}$ See Caliendo et al. (2014) for a detailed correlation analysis, further validity checks of the personality constructs, and a factor analysis. The latter also shows that it makes sense to use distinct indicators for internal and external locus of control.
} 
before entering self-employment. On average, women score significantly higher than men in all Big Five personality traits. They are more open to experience, more conscientious, extraverted, and agreeable ${ }^{13}$, but also emotionally less stable. There are also significant mean differences by gender in some specific personality characteristics. Men are more risk tolerant and exhibit a more internal and less external locus of control. Trust is the only personality variable that does not differ by gender.

$<$ Insert Table 1 about here $>$

The socio-demographic variables confirm expectations. Men and women in the sample are of the same average age, but men have accumulated 3.5 more years of work experience. 19 percent of the women are not participating in the labour market, while this holds only for 1 percent of the men. ${ }^{14}$ Moreover, in our sample of working-aged persons, women still have a significantly lower education than men. Only 25 percent of them possess a highschool degree that qualifies them for university entrance (Abitur), as opposed to 30 percent of the men, and only 20 percent of the women earned a university degree, in contrast to 25 percent of the men. ${ }^{15}$

In the sub-sample of nascent entrepreneurs (entry sample), the significant gender differences in the personality traits point to the same directions as in the full sample (only for conscientiousness, the difference is no longer statistically significant). Both men and women who enter into self-employment are more risk tolerant than those who do not enter. Furthermore, men and women, who enter self-employment have on average less work experience and more unemployment experience than those who do not enter; consistently, they are unemployed or not participating in the labour market more often as well. Entrants of both genders are better educated than non-entrants: They more often possess a high-school degree qualifying for university entrance and a university degree, but less

\footnotetext{
${ }^{13}$ See Pan and Houser (2011) on gender differences in pro-sociality.

${ }^{14}$ Milligan (2014) concludes from his empirical analysis that the gender gap in parental employment stayed high in Germany in comparison to the USA, the UK, and Canada, until Germany expanded public childcare provision in the 2000s.

${ }^{15}$ The dummy variables for schooling are not mutually exclusive; somebody may have a high-school degree, vocational training and a university degree at the same time, for example.
} 
often finished vocational training. Average capital income is also higher for the entrants of both genders. ${ }^{16}$

Table A.3 in the Appendix shows which industries men and women choose when they enter entrepreneurship, i.e., the industries the new entrants report in their first year of self-employment. The most significant difference is that 13 percent of the male, but only 2 percent of the female start-ups are in the construction industry. Furthermore, men more often start businesses in the manufacturing and private services industries (financial intermediation, personal and business services), whereas women more often choose the public and social services sector (education, health).

\subsection{Decomposition}

To analyse the gender gap in the rate of entrepreneurial entry, we first estimate logit models for the probability of becoming self-employed, separately for men and women. ${ }^{17}$ The binary outcome variable entry $y_{(i, t+1)}$ equals 1 if individual $i$ enters self-employment between years $t$ and $t+1$, and 0 otherwise. The latent index function of the logit model is written as

$$
\operatorname{entry}_{(i, t+1)}^{*}=X_{i t} \beta+\epsilon_{i t},
$$

where entry* is the propensity to enter self-employment, $X$ is a vector of explanatory variables that includes the personality characteristics, $\beta$ is a coefficient vector including a constant, and $\epsilon$ is an error term. We decompose the gender gap in the mean entry

\footnotetext{
${ }^{16}$ In the full sample of those not self-employed, the capital income of the household is higher on average for women than for men. In contrast to all other variables that each household member is asked individually, based on the personal questionnaire of the SOEP, capital income is elicited for the household as a whole using the household questionnaire, and then assigned to each household member. The higher average household capital income of women is explained by the fact that the self-employed, who on average have more capital income, are not in the estimation sample at risk of entering into self-employment, i.e., mostly men, while their wives are included in the sample, such that their households' capital income only appears in the women's average. Note that capital income is distributed very unequally; the medians are closer together, 0.22 for men and 0.24 for women.

${ }^{17}$ The results from the decomposition are qualitatively similar when we estimate a logit model of the probability of being self-employed instead of the probability of entry into self-employment, although this does not allow assessing the role of the current employment state. We prefer the entry model because here, all the explanatory variables are observed before a potential transition occurs, whereas in the model of self-employment state, the explanatory variables may be influenced by the current state, which is the dependent variable.
} 
probability into a part explained by gender differences in endowments, including the scores in the personality traits, and an unexplained part reflected in differences in the coefficients and the intercept. The detailed decomposition allows assessing separately the contribution of each variable of interest.

Among the explanatory variables in $X$, we have a special interest in those traits which have not been used in such an analysis before, the Big Five traits, but also in specific personality characteristics such as risk tolerance, locus of control, and trust. To capture human capital, we include years of work experience and unemployment experience as well as dummy variables for educational degrees obtained: High school, i.e., university entrance qualification, vocational training, technical college, and university. These degree dummies are not mutually exclusive; for example, many individuals have earned a high-school degree and also finished vocational training. ${ }^{18}$ We also control for a self-employed father when the respondent was 15 years old. ${ }^{19}$ Self-employment of parents is likely to have an effect on the probability of offspring's self-employment, e.g. through inheritance of a business. At the same time, parental self-employment is likely to be correlated with own personality characteristics due to intergenerational transmission of personality (Anger, 2012), so it is an important control variable to avoid omitted variable bias in the coefficients of the personality variables. As an indicator of wealth, we include capital income defined as the sum of income from interests, dividends, and house rents of the respondent's household (these variables are not available on the individual, but only on the household level on an annual basis). We further control for age (linear and squared), current employment status (unemployed, not participating, or employed), marital status, number of children, disability status, German nationality, as well as regional and year dummy variables (see Table A.5 in Appendix A for variable descriptions). While we consider this set of explanatory variables very comprehensive, we might still miss relevant variables, which would tend to

\footnotetext{
${ }^{18}$ See Table 1 for the shares of respondents with the respective educational degrees in the sample. They add up to more than 100 percent because of the possibility of multiple degrees. There are also persons who have none of these degrees.

${ }^{19}$ Self-employed mothers were very rare in the generation of most respondents' parents, and the information on mother's occupation is often missing in the data, so we do not include mother's self-employment status.
} 
increase the unexplained part in the decomposition analysis. ${ }^{20}$

We follow an adaption of the decomposition approach originally suggested by Oaxaca (1973) and Blinder (1973); Fortin et al. (2011) provide an overview. As we have a binary outcome variable and estimate logit models, we apply the weighting method for nonlinear models as described by Yun (2004), which allows for a detailed decomposition by single variables as well as coefficients. ${ }^{21} \mathrm{~A}$ well-known issue pertains to whether the coefficients for men or women should be used to assess the contribution of the variables to the gender gap (index problem). Therefore, we follow Neumark (1988) and Oaxaca and Ransom (1994) and use the coefficients from an estimation of the logit model of entry on the pooled sample of men and women. We include a gender dummy in the pooled model, as recommended by Jann (2008), to avoid a potential spillover from the unexplained part of the differential into the explained component which may result from omitting the group variable. Furthermore, we normalise categorical variables such as the dummy variables describing the employment state. As a result, effects are expressed as deviations from the overall mean, and the detailed decomposition results do not depend on the choice of an otherwise arbitrarily omitted base category (Yun, 2005). We report standard errors robust to heteroskedasticity and clustering on the individual level, which we obtain by means of the delta method (cf. Jann, 2008). We describe this variant of a nonlinear decomposition formally in Appendix B.

\section{Empirical Results}

\subsection{Probability Model of Entry into Self-Employment}

The first step in the decomposition analysis is the estimation of the logit model of the probability of entry into self-employment separately for men and women and for the pooled sample. We conduct the decomposition with two sets of personality variables: First, we

\footnotetext{
${ }^{20}$ A fixed effects specification could be considered to remove unobserved time invariant individual heterogeneity, but this would not allow analysing the role of personality characteristics, which are mostly stable over time for adults.

${ }^{21}$ Fairlie (1999), Fairlie (2005) and Fairlie and Robb (2007) suggest an alternative decomposition method for nonlinear models that has been applied for detailed decomposition by variables, but not by coefficients. The results from our decomposition concerning the variables are similar when Fairlie's method is used.
} 
only include the Big Five traits, and second, we additionally include the specific personality characteristics; while the socio-demographic controls always enter the estimations. Table 2 provides the estimated marginal effects of the two sets of personality traits and selected other variables on the probability of entry for men and women (the logit coefficients of all explanatory variables for both genders and the pooled sample appear in Table A.4 in Appendix A). The results indicate that while we control for all kinds of sociodemographic and educational variables, personality traits influence the entry decision into entrepreneurship.

Most notably, risk attitudes and locus of control have significant partial effects even after controlling for the Big Five traits and for the typically used socio-demographic variables. Thus, the Big Five model does not capture all aspects of personality relevant for entrepreneurial entry, in line with the conclusion of Caliendo et al. (2014), which is why we prefer the more comprehensive specification. Risk tolerance increases the probability of entry for both, men and women. ${ }^{22}$ A more internal and a less external locus of control consistently increase the probability of becoming self-employed, but this holds only for men; for women, we do not find any significant effect of locus of control.

$<$ Insert Table 2 about here $>$

Turning to the Big Five, openness to experiences has a positive and highly significant effect on the entry probability in both specifications and for both genders. If openness increases by one standard deviation, the probability of entry increases by 0.12 percentage points for men and even by 0.21 percentage points for women, based on the full models. Relative to the mean entry rate of 1.01 percent (1.35 percent) for women (men), this is an increase by 20.8 percent (8.9 percent). Extraversion and agreeableness increase the entrance probability significantly for men only. While Caliendo et al. (2014) found similar positive effects of openness and extraversion for the pooled sample, they did not distinguish by gender and were not able to reveal gender differences in the effects of extraversion and

\footnotetext{
${ }^{22}$ The willingness to take risk enters the model as a quadratic function; the marginal effect of an increase by one point on the 11-point scale is estimated at the mean risk tolerance level.
} 
agreeableness on the entry decision into entrepreneurship. Thus, overall we observe that personality traits have differing impacts on the entry probabilities of both genders.

The socio-demographic variables reveal interesting gender differences as well. Those currently unemployed or not participating have significantly higher entry probabilities than paid employees. This is true for both genders, but the point estimates of the partial effects are larger for men. These effects can be explained by the opportunity costs of employees which on average are higher for men because of higher wages.

Education increases the probability of entry into self-employment, as indicated by the positive coefficients of a university entrance qualification (high-school) and a university degree; the latter is statistically significant for men only. Vocational training decreases the entry probability for women. Interestingly, higher capital income of the household significantly increases the entrance probability for men only. We interpret this observation in the sense, that men have better access to their household's financial resources for investments in their businesses than women. Intergenerational links seem to be gender specific as well: A self-employed father (when the respondent was 15 years old) significantly increases the likelihood of entrepreneurial entry for women only. ${ }^{23}$

$<$ Insert Table 3 about here $>$

How much do the socio-demographic variables and the personality characteristics explain the gender gap in the probability of entry into self-employment? A first simple approach consists in starting with a logit model based on the pooled sample, but with a female dummy variable as the only explanatory variable, and successively adding explanatory variables. The discrete effects of the female indicator appear in Table 3. Without further controls, being female decreases the probability of entry by 0.34 percentage points (this corresponds to the raw gap between the entry rates). First adding the sociodemographic controls and then the Big Five traits does not reduce this unexplained gender gap, as perhaps expected, but increases it further. Thus, the raw gender gap is not due to

\footnotetext{
${ }^{23}$ Interestingly, for English data, Schoon and Duckworth (2012) also find differing influences of parents on the two genders, even if their findings are not in line with ours.
} 
omitting these variables in the first column. Only when the specific personality characteristics (risk, locus of control, and trust) are included, the partial effect of the female dummy decreases (in absolute terms) to -0.26 percentage points. This means that, among these groups of variables, only the gender differences in the specific personality characteristics contribute to partially explaining the gap.

\subsection{Nonlinear Decomposition by Variables and Coefficients}

To systematically explore the gender gap in the entry probability, we conduct our variant of a nonlinear Oaxaca-Blinder decomposition based on the estimated logit models discussed in the previous subsection. ${ }^{24}$ The first three columns of Table 4 present the results from the model employing the Big Five as the only personality traits, and the other three columns the results from the preferred model additionally including the specific personality characteristics; all models adopt the full set of socio-demographic variables. The first three rows redisplay the annual entry rates for men and women and the raw differential between them of 0.34 percentage points, which is significantly different from zero at the one percent level. This raw differential is decomposed into a part explained by gender differences in endowments, i.e., in the variables, and an unexplained part. The latter is due to gender differences in the coefficients, which reflect the influence of the variables on the entry probability, and in the constant. In the preferred comprehensive model on the right hand side of the table, the explained gap is -0.16 percentage points, i.e. -46 percent of the raw differential (see next column), and the unexplained gap (further below in the table) is 0.50 percentage points, i.e. 146 percent (the two components sum up to the raw gap). Both parts are significant. The finding that the explained part is negative can be interpreted as follows: If women were more similar to men in all the explanatory variables (including personality), their entry rate into self-employment would be even lower and the gender gap would be larger. Therefore, the unexplained gender gap is larger than the raw gap.

$<$ Insert Table 4 about here $>$

\footnotetext{
${ }^{24}$ The only difference between the logit models in Tables 2 and A.4 and those used in the decomposition is that for the decomposition, categorical variables are orthogonalised, see Section 3.4. This does not change the coefficients of the other variables.
} 
We further decompose both, the explained and the unexplained gaps. We start with the detailed decomposition of the explained part into the contributions of single variables and groups of variables. As a group, the Big Five traits contribute negatively to the explained part, which means that they additionally increase the unexplained gender gap. Further decomposition shows that among the Big Five, only openness to experience contributes significantly to the explained gap in the comprehensive model. The negative contribution is explained by the fact that openness to experience increases the probability of entry (see Table 2), and women score higher in this trait on average (see Table 1). Thus, if women were more similar to men, they would be less open and have a lower probability of entry - this result widens the unexplained gender gap. In contrast, the specific personality characteristics explain a very important part of the gap, i.e. 0.27 percentage points or 79 percent of the raw gap. Almost all of this can be attributed to risk attitudes, the only individually significant characteristic when this group is further decomposed. Here, the explanation is that risk tolerance increases the entrance probability, and women are on average less willing to take risks than men. Hence, accounting for differences in risk attitudes reduces the unexplained gender gap. This can be observed in the first three columns of the table, where risk attitude is omitted: Here, the explained gap is more negative and the unexplained part is much larger. We conclude that risk attitude is an important variable to explain the gender gap, and a substitution by the Big Five traits is not possible.

The decomposition of the socio-demographic variables yields further interesting insights; we will discuss the statistically significant contributions in the preferred model. Different levels of education explain 28 percent of the raw gender gap; more specifically, the lower shares of women with a high school degree and a university degree explain 18 percent and 14 percent of the gap, respectively, since both attainments increase the probability of entrepreneurial entry (see Table 2). The single variable most contributing to the negative explained part of the gap is the dummy indicating wage employment. Paid employment decreases the probability of becoming self-employed both for men and women 
(Table 2) because of higher opportunity costs, ceteris paribus. ${ }^{25}$ At the same time, a smaller share of women is employed in Germany in comparison to men. Thus, from the effect of the employment state and the distribution, one would expect a higher entry rate among women. This implies that accounting for the labour market status in the model decreases the explained part and further increases the unexplained part of the gender gap. The family situation does not explain the gender gap: The number of children is insignificant in the logit estimations of entry for men and women, and being married is insignificant for women and negatively associated with entry for men (Table A.4). Finally, capital income of the household also increases the unexplained gap, but only by 2.6 percent of the raw gap per 1000 euro.

In the decomposition of the unexplained gap, only two of the contributions of single (groups of) coefficients are statistically significant. The most important one is the dummy indicating that someone finished vocational training. It contributes 0.47 percentage points to the unexplained part (which is 0.50 percentage points in total). Table 1 shows that the share of women with vocational training in the estimation sample is only 3.4 percentage points below the share of men, but in the subsample of those who are about to enter self-employment, the gender difference is 11.5 percentage points. This is reflected in the estimated logit model, which reveals that vocational training decreases the probability of entry for women, but not for men (see Table 2). This gender difference in the influence of vocational training (while the distribution is similar) constitutes the significant contribution of vocational training to the unexplained gap. A likely explanation is that men choose apprenticeships in industries that exhibit higher self-employment rates, such as construction (cf. Table A.3). The second significant, albeit smaller, contribution to the unexplained gap is that of the coefficient of capital income. The effect of capital income is positive for men, but insignificant for women. As mentioned in the previous subsection,

\footnotetext{
${ }^{25}$ To check the opportunity costs argument, one might consider including the current income as a paid employee in the model. We do not do so because labour income is likely to be endogenous, for example, because prospective entrepreneurs reduce their work hours to make preparations for their future start-up. We also considered temporary employment contracts and included a dummy variable controlling for a fixed-term employment status before entering self-employment in the estimation. We find an insignificant effect of temporary employment on the entry probability and for the decomposition results. Therefore, we decided not to include the temporary employment dummy in our final estimation specification.
} 
it is possible that men have more control over the household's capital and can easier use it to start up a business than women. This result points to an unequal intra-household distribution of power over financial resources. ${ }^{26}$

One might expect that the gender difference in the propensity to become an entrepreneur could differ by religion or cultural background. Our explanatory variables include regional dummies, which proxy religion in the sense that the East and North of Germany are predominantly Lutheran, while the South is more Catholic. Region neither contributes significantly to the explained, nor to the unexplained part, however. Likewise, the dummy variable indicating German nationality does not have any significant contribution in the decomposition. The largest immigrant group to Germany are from Turkey, who are predominately Muslim. In sum, our results do not point to differences in the entrepreneurship gender gap by religion.

\section{Discussion and Conclusion}

Based on the German Socio-Economic Panel, we decompose the gender gap in entry rates into self-employment by the most influential factors, including human capital, employments status and personality traits. We find that the overall gender gap can be split into a negative explained gap due to different distributions of characteristics and a positive unexplained gap due to different influences of these characteristics on the entry probability. This means that given their current characteristics, women should have a higher entry rate into self-employment than men (negative explained gap), but due to a less favourable rewarding of their characteristics with respect to entrepreneurial entry (positive unexplained gap) the female entry rate remains lower than that of males. Looking at the explained part of the gap, we find a strong influence and explanatory power of three groups of variables: Education, employment status, and personality characteristics.

\footnotetext{
${ }^{26}$ Alesina et al. (2013) report that women pay more for credit than men in Italy. From this result alone, if it is applicable to Germany, we would expect that capital income (as an indicator for capital assets) should have a more positive effect on the probability of entry into entrepreneurship for women than for men, because women would depend more on own wealth, whereas men would find it easier to borrow and start up a business even when lacking own assets. The fact that we do not find this (cf. Table 2) is consistent with the interpretation that men control the household's capital assets, so household wealth does not help women to start up a business.
} 
With respect to the role of endowments in the gender gap in entrepreneurial entry, the largest explanatory power among the personality characteristics is found when looking at the specific personality characteristics beyond the Big Five construct. The lower willingness to take risk among women explains almost three quarters of the overall gender differential. Women are, on average, more risk averse and therefore less likely to choose the transition into entrepreneurship. In contrast, the distribution of the traits of the Big Five Factor Model would rather imply a higher entry rate into self-employment for female individuals. Women score higher on average in openness to experience and extraversion than men and should therefore choose self-employment more often than observed. With respect to other traits, we find no or only small effects on the gender gap. Overall, it seems that beyond risk attitudes the explanatory power of personality characteristics for the gender gap is lower and different from what is mostly expected.

Looking at variables beyond traits, the lower average educational level of women explains about a quarter of the gender differential in the transition rate. Since today (unlike in the last century) as many women graduate from university as men in Germany, we can expect that the gender gap in entrepreneurship will become smaller in the future. ${ }^{27}$ The current labour market status has another strong effect. Women have a lower rate of wage employment and are more often not participating, which, per se, would imply a higher transition rate into self-employment, holding everything else constant, such as education, work experience, and the family situation. This effect significantly reduces the explained gap of our model.

Decomposing the unexplained gender gap in the entry probability, we find significant gender differences only for two variables: vocational training, suggesting that men take apprenticeships in industries with higher self-employment rates, and capital income, suggesting that women have less control over the household's capital than men when it comes to investments in their business start-up. These findings are in line with most of previous research. Similar to our results, Georgellis and Wall (2005) report a higher influence of

\footnotetext{
${ }^{27}$ The share of female university graduates rose steadily in post-war Germany and has reached, and even surpassed in some years, the male share, since about 2005 (Federal Statistical Office, 2013).
} 
capital for men. Rosti and Chelli (2005) find a large effect of the current employment status on the transition rates into self-employment for Italy. The explanatory power of risk preferences is demonstrated by Fossen (2012), Bönte and Piegeler (2013), and Furdas and Kohn (2010). In contrast to our results, Bönte and Piegeler (2013) report a significant influence of competitiveness, which can be regarded as a component of the personality trait conscientiousness. Controlling for a wider range of personality characteristics, we do not find a significant effect of conscientiousness anymore. In this sense, we are able to control, in contrast to prior research, for a wide variety of socio-demographic and personality variables simultaneously. Our analysis demonstrates the importance of controlling for a full set of personality characteristics, employment status and human capital instead of picking single variables.

Our results clearly indicate that policy measures aiming to close the gender gap need to tackle the problem of differing risk attitudes, e.g. by offering public risk-sharing to (female) entrepreneurs. One solution to this problem was found by Caliendo and Kritikos (2010). They point to an earlier German start-up subsidy programme, which was available between 2003 and 2006, and which offered a fixed, but over the years diminishing amount, of financial support to founders out of unemployment for up to three years. This programme facilitated the step into self-employment for women, and the form of security offered by this specific design substantially increased the number of female applications to this support programme. While the male over female ratio is about 2:1 in most other programmes supporting business venturing in Germany, the share in this programme was equally distributed between men and women. It helped to reduce the entrepreneurial gender gap in Germany during this time.

Based on our other findings, we propose three further policy measures. These relate to coaching, campaigning and capital access as an integrated concept to promote female self-employment. Externally provided professional coaching combines the enhancement of education-related skills, which might be less pronounced among higher aged female nascent entrepreneurs, with elements that support entrepreneurial decision making. Offered at an 
early stage, it might be an instrument that helps increase the number of potential female entrepreneurs who are planning to enter entrepreneurial activities, but so far refrained from doing so. ${ }^{28}$ Secondly, given the large unexplained gender gap in entrepreneurship, female entries into the start-up scene could also be promoted by public campaigns aiming at a de-stigmatization of female entrepreneurship. Last but not least, access to capital seems to be more difficult for women than for men. At the same time, we observe that female entrepreneurs are still less risk tolerant than their male counterparts, which might make them less open to loans as typical instrument of financing their businesses. Moreover, Alesina et al. (2013) reveal differing accesses to credit lines for women compared to men with women again being disadvantaged. This may point to specific needs of female entrepreneurs for different kinds of capital access, for instance equity or mezzanine capital.

Putting our findings together, we reveal that after controlling for the most important factors influencing the decision to become self-employed, the overall explained gender gap in entry into entrepreneurship is negative. Hence, given the distribution of their characteristics, women should be more likely to enter self-employment than men or, in other words, if women had on average the same characteristics as men, their entrepreneurial activity would be even lower. This effect widens the unexplained gender gap in entrepreneurship and suggests that the lower entry rate of women is also due to unobservable influences directly connected to gender. Reasons for these unobservable differences might be discrimination by customers (Borjas and Bronars, 1989) and capital providers (Georgellis and Wall, 2005; Alesina et al., 2013), cultural aspects (Campa et al., 2011) or different social and family roles or preferences (Verheul et al., 2012). The challenge for future research is to investigate the relative importance of these possible mechanisms. Another interesting avenue for the future is to assess gender differences in the success of entrepreneurial activities, which could be defined in terms of income, business growth, or survival of the ventures, and how such possible differences are related to personality.

\footnotetext{
${ }^{28}$ Regarding the lower willingness to take risk for women, Booth and Nolen (2012) find a significantly higher risk preference for girls taught at single-sex schools or in all-girls groups, compared to their co-ed counterparts. This effect might also be of interest for entrepreneurial coaching strategies directed at women.
} 


\section{References}

Alesina, A. F., F. Lotti, and P. E. Mistrulli (2013). Do women pay more for credit? Evidence from Italy. Journal of the European Economic Association 11, 45-66.

Anger, S. (2012). The intergenerational transmission of cognitive and non-cognitive skills during adolescence and young adulthood. SOEPpapers on Multidisciplinary Panel Data Research 473, DIW Berlin, The German Socio-Economic Panel (SOEP).

Antecol, H. (2000). An examination of cross-country differences in the gender gap in labor force participation rates. Labour Economics 7(4), 409-426.

Blanchflower, D. (2000). Self-employment in OECD countries. Labour Economics 7, 471505.

Blanchflower, D. and A. Oswald (1998). What makes an entrepreneur? Journal of Labor Economics 16, 26-60.

Blinder, A. (1973). Wage discrimination: Reduced form and structural estimates. Journal of Human Resources 8, 436-55.

Booth, A. L. and P. Nolen (2012). Gender differences in risk behaviour: Does nurture matter? The Economic Journal 122(558), 56-78.

Borghans, L., A. L. Duckworth, J. J. Heckman, and B. t. Weel (2008). The economics and psychology of personality traits. Journal of Human Resources 43(4), 972-1059.

Borjas, G. and S. Bronars (1989). Consumer discrimination and self-employment. Journal of Political Economy 97, 581-605.

Bönte, W. and M. Piegeler (2013). Gender gap in latent and nascent entrepreneurship: Driven by competitiveness. Small Business Economics 41(4), 961-987.

Caliendo, M., F. Fossen, and A. Kritikos (2009). Risk attitudes of nascent entrepreneurs new evidence from an experimentally validated survey. Small Business Economics 32, $153-167$.

Caliendo, M., F. Fossen, and A. Kritikos (2012). Trust, positive reciprocity, and negative reciprocity: Do these traits impact entrepreneurial dynamics? Journal of Economic Psychology 33(2), 394-409.

Caliendo, M., F. Fossen, and A. Kritikos (2014). Personality characteristics and the decisions to become and stay self-employed. Small Business Economics 42(4), 787-814.

Caliendo, M. and A. Kritikos (2010). Start-ups by the unemployed: Characteristics, survival and direct employment effects. Small Business Economics 35(1), 71-92.

Campa, P., A. Casarico, and P. Profeta (2011). Gender culture and gender gap in employment. CESifo Economic Studies 57(1), 156-182.

Cobb-Clark, D. and S. Schurer (2012). The stability of Big-Five personality traits. Economics Letters 115(1), 11-15.

Cobb-Clark, D. A. and S. Schurer (2013). Two economists' musings on the stability of Locus of Control. Economic Journal 123(570), F358-F400.

Cramer, J., J. Hartog, N. Jonker, and C. Van Praag (2002). Low risk aversion encourages the choice for entrepreneurchip: An empircal test of a truism. Journal of Economic Behavior and Organization 48, 29-36. 
Croson, R. and U. Gneezy (2009). Gender differences in preferences. Journal of Economic Literature 47(2), 448-474.

Dohmen, T., A. Falk, D. Huffman, U. Sunde, J. Schupp, and G. G. Wagner (2007). Risk as a personality trait: On the stability of risk attitudes. Technical report, Berlin.

Dustmann, C. (2005). The assessment: Gender and the life cycle. Oxford Review of Economic Policy 21(3), 325-339.

Evans, D. and L. Leigthon (1989). Some empirical aspects of entrepreneurship. American Economic Review 79, 519-535.

Fairlie, R. W. (1999). The absence of the African-American owned business: An analysis of the dynamics of self-employment. Journal of Labor Economics 17(1), 80-108.

Fairlie, R. W. (2005). An extension of the Blinder-Oaxaca decomposition technique to logit and probit models. Journal of Economic and Social Measurement 30(4), 305-316.

Fairlie, R. W. and A. M. Robb (2007). Why are black-owned businesses less successful than white-owned businesses? The role of families, inheritances, and business human capital. Journal of Labor Economics 25(2), 289-323.

Federal Statistical Office (2013). Entwicklung des Studentinnenanteils in Deutschland (1908-2012) [Development of the share of female university students in Germany (19082012)]. http://www.gesis.org/cews/fileadmin/cews/www/statistiken/05_d.gif, last accessed November 30, 2013.

Fortin, N., T. Lemieux, and S. Firpo (2011). Chapter 1 - decomposition methods in economics. Volume 4, Part A of Handbook of Labor Economics, pp. 1 - 102. Elsevier.

Fossen, F. M. (2012). Gender differences in entrepreneurial choice and risk aversion - a decomposition based on a microeconometric models. Applied Economics 44(14), 17951812 .

Furdas, M. and K. Kohn (2010). What's the difference?! Gender, personality, and the propensity to start a business. IZA Discussion Papers 4778, Institute for the Study of Labor (IZA).

Georgellis, Y. and H. J. Wall (2005). Gender differences in self-employment. International Review of Applied Economics 19(3), 321-342.

Global Entrepreneurship Monitor (2005). The definitive study of entrepreneurship in 2005. Babson College.

Jann, B. (2008). The Blinder-Oaxaca decomposition for linear regression models. Stata Journal 8(4), 453-479.

Kan, K. and W.-D. Tsai (2006). Entrepreneurship and risk aversion. Small Business Economics 26, 465-474.

Kelley, D. J., C. G. Brush, P. G. Greene, and Y. Litovsky (2013). Global entrepreneurship monitor: 2012 women's report. Technical report, Global Entrepreneurship Research Association.

Koellinger, P., M. Minniti, and C. Schade (2013). Gender differences in entrepreneurial propensity. Oxford Bulletin of Economics and Statistics 75(2), 213-234.

Lang, F. R., D. John, O. Lüdtke, J. Schupp, and G. Wagner (2011). Short assessment of the Big Five: Robust across survey methods except telephone interviewing. Behavior Research Methods 43(2), 548-567. 
Lazear, E. P. (2004). Balanced skills and entrepreneurship. The American Economic Review 94(2), 208-211.

McCrae, R. R. and P. T. Costa (2008). The five-factor theory of personality. In O. P. John, R. Robins, and L. Pervin (Eds.), Handbook of Personality: Theory and Research, pp. 159-181. New York: Guilford.

Milligan, K. (2014). The road to egalitaria: Sex differences in employment for parents of young children. CESifo Economic Studies, First published Feburary 26, 2014, doi:10.1093/cesifo/ifu008.

Neumark, D. (1988). Employers' discriminatory behavior and the estimation of wage discrimination. The Journal of Human Resources 23(3), 279-295.

Norton, W. and W. Moore (2006). The influence of entrepreneurial risk assessment on venture launch or growth decision. Small Business Economics 26, 215-226.

Oaxaca, R. (1973). Male-female wage differentials in urban labor markets. International Economic Review 14, 693-709.

Oaxaca, R. L. and M. R. Ransom (1994). On discrimination and the decomposition of wage differentials. Journal of Econometrics 61(1), 5-21.

Pan, X. and D. Houser (2011). Mating strategies and gender differences in pro-sociality: Theory and evidence. CESifo Economic Studies 57(4), 653-682.

Piorkowsky, M., M. Buddensiek, and R. H. Eschweiler (2013). Selbstständige in Deutschland 1992-2011. Technical report, University Bonn.

Rauch, A. and M. Frese (2007). Let's put the person back into entrepreneurship research: A meta-analysis on the relationship between business owners' personality traits, business creation, and success. European Journal of Work and Organizational Psychology 16, $353-385$.

Rosa, P., S. Carter, and D. Hamilton (1996). Gender as a determinant of small business performance: Insights from a British study. Small Business Economics 8(6), 463-478.

Rosti, L. and F. Chelli (2005). Gender discrimination, entrepreneurial talent and selfemployment. Small Business Economics 24(2), 131-142.

Schmitt, D. P., A. Realo, M. Voracek, and J. Allik (2008). Why can't a man be more like a woman? Sex differences in Big Five personality traits across 55 cultures. Journal of Personality and Social Psychology Vol 94(1), 168-182.

Schoon, I. and K. Duckworth (2012). Who becomes an entrepreneur? Early life experiences as predictors of entrepreneurship. Developmental Psychology 48, 1719-1726.

Sherman, A. C., G. E. Higgs, and R. L. Williams (1997). Gender differences in the locus of control construct. Psychology \& Health 12(2), 239-248.

Socio-Economic Panel (SOEP). Data for years 1984-2010, version 27, SOEP, 2010, doi:10.5684/soep.v27.

Van Der Sluis, J., M. Van Praag, and W. Vijverberg (2008). Education and entrepreneurship selection and performance: A review of the empirical literature. Journal of Economic Surveys 22(5), 795-841.

Verheul, I., R. Thurik, I. Grilo, and P. van der Zwan (2012). Explaining preferences and actual involvement in self-employment: Gender and the entrepreneurial personality. Journal of Economic Psychology 33(2), 325-341. 
Wagner, G., J. Frick, and J. Schupp (2007). The German Socio-Economic Panel Study (SOEP): Scope, evolution and enhancements. Schmollers Jahrbuch 127(1), 139-170.

Wagner, J. (2007). What a difference a Y makes - female and male nascent entrepreneurs in Germany. Small Business Economics 28, 1-21.

Weisberg, Y. J., C. G. DeYoung, and J. B. Hirsh (2011). Gender differences in personality across the ten aspects of the Big Five. Frontiers in Psychology 2(178), 1-11.

Yun, M.-S. (2004). Decomposing differences in the first moment. Economics Letters 82(2), $275-280$.

Yun, M.-S. (2005). Normalized equation and decomposition analysis: Computation and inference. IZA Discussion Papers 1822, Institute for the Study of Labor (IZA).

Zhao, H. and S. Seibert (2006). The Big Five personality dimensions and entrepreneurial status. Journal of Applied Psychology 91(2), 259-271. 


\section{Tables}

Table 1: Mean characteristics by gender

\begin{tabular}{|c|c|c|c|c|c|c|}
\hline \multirow[b]{2}{*}{ Variable } & \multicolumn{3}{|c|}{ Full estimation sample } & \multicolumn{3}{|c|}{ Entry sample } \\
\hline & Men & Women & p-Value & Men & Women & p-Value \\
\hline Entry rate & 0.0135 & 0.0101 & 0.0001 & 1.0000 & 1.0000 & \\
\hline \multicolumn{7}{|l|}{ Big 5} \\
\hline Openness & 4.3869 & 4.5671 & 0.0000 & 4.7754 & 5.0938 & 0.0001 \\
\hline Conscientiousness & 5.9522 & 6.0520 & 0.0000 & 5.9443 & 5.9959 & 0.4573 \\
\hline Extraversion & 4.6840 & 4.9733 & 0.0000 & 5.0018 & 5.1621 & 0.0446 \\
\hline Agreeableness & 5.2477 & 5.5697 & 0.0000 & 5.3802 & 5.5576 & 0.0112 \\
\hline Neuroticism & 3.6563 & 4.1290 & 0.0000 & 3.5022 & 4.0082 & 0.0000 \\
\hline \multicolumn{7}{|l|}{ Other Personality Traits } \\
\hline Risk & 5.0249 & 4.1681 & 0.0000 & 6.0159 & 5.0550 & 0.0000 \\
\hline Internal LOC & 5.4600 & 5.4433 & 0.0146 & 5.6004 & 5.4699 & 0.0417 \\
\hline External LOC & 3.3204 & 3.4220 & 0.0000 & 3.1516 & 3.3236 & 0.0244 \\
\hline Trust & 2.3312 & 2.3300 & 0.7876 & 2.4182 & 2.4261 & 0.8531 \\
\hline \multicolumn{7}{|l|}{ School leaving degree } \\
\hline High-School & 0.3038 & 0.2453 & 0.0000 & 0.4934 & 0.4281 & 0.0836 \\
\hline Vocational training & 0.5380 & 0.5045 & 0.0000 & 0.4668 & 0.3517 & 0.0019 \\
\hline Technical college & 0.2295 & 0.2795 & 0.0000 & 0.2202 & 0.2966 & 0.0203 \\
\hline University & 0.2479 & 0.1976 & 0.0000 & 0.4085 & 0.3609 & 0.1960 \\
\hline Age & 41.41 & 41.43 & 0.79 & 40.15 & 40.11 & 0.95 \\
\hline Yrs work experience/10 & 1.9583 & 1.6072 & 0.0000 & 1.7119 & 1.3505 & 0.0000 \\
\hline Yrs unempl. experience/10 & 0.0586 & 0.0696 & 0.0000 & 0.0735 & 0.0870 & 0.2398 \\
\hline Disabled & 0.0649 & 0.0468 & 0.0000 & 0.0557 & 0.0275 & 0.0650 \\
\hline German & 0.9498 & 0.9540 & 0.0158 & 0.9443 & 0.9450 & 0.9697 \\
\hline SE father & 0.0686 & 0.0707 & 0.3153 & 0.1141 & 0.1223 & 0.7349 \\
\hline \# of children & 0.7389 & 0.7507 & 0.1361 & 0.7772 & 1.0245 & 0.0017 \\
\hline Married & 0.6946 & 0.7297 & 0.0000 & 0.6180 & 0.7554 & 0.0001 \\
\hline Divorced & 0.0616 & 0.0817 & 0.0000 & 0.0637 & 0.0612 & 0.8916 \\
\hline East Germany & 0.2812 & 0.2676 & 0.0002 & 0.3448 & 0.2569 & 0.0114 \\
\hline South Germany & 0.2749 & 0.2663 & 0.0174 & 0.2440 & 0.2905 & 0.1641 \\
\hline North Germany & 0.1057 & 0.1116 & 0.0217 & 0.0796 & 0.1040 & 0.2620 \\
\hline City States & 0.0183 & 0.0181 & 0.8525 & 0.0080 & 0.0245 & 0.0784 \\
\hline Capital income/1000 in EUR & 2.1292 & 2.9371 & 0.0000 & 9.0557 & 4.6747 & 0.0467 \\
\hline Unemployed & 0.0626 & 0.0579 & 0.0155 & 0.2653 & 0.1651 & 0.0013 \\
\hline Not participating & 0.0101 & 0.1906 & 0.0000 & 0.0318 & 0.3242 & 0.0000 \\
\hline \# of person-years & 27,902 & 32,411 & & 377 & 327 & \\
\hline
\end{tabular}

Notes: The full estimation sample includes all observations of persons not currently self-employed; the entry sample those who we observe just before entering self-employment. The p-values refer to t-tests of equal means by gender. Detailed information on all variables are provided in Table A.5 in Appendix A.

Source: Authors' calculations based on the SOEP (2000-2010). 
Table 2: Logit estimation of the probability of entry into selfemployment: Marginal effects

\begin{tabular}{|c|c|c|c|c|}
\hline \multirow{2}{*}{ Big 5} & \multicolumn{2}{|c|}{ Men } & \multicolumn{2}{|c|}{ Women } \\
\hline & & & & \\
\hline Std Openness & $\begin{array}{c}0.0019^{* * *} \\
(0.0005)\end{array}$ & $\begin{array}{c}0.0012^{* * *} \\
(0.0004)\end{array}$ & $\begin{array}{c}0.0028^{* * *} \\
(0.0004)\end{array}$ & $\begin{array}{c}0.0021^{* * * *} \\
(0.0004)\end{array}$ \\
\hline Std Conscientiousness & $\begin{array}{c}-.0003 \\
(0.0006)\end{array}$ & $\begin{array}{c}-.0006 \\
(0.0004)\end{array}$ & $\begin{array}{c}-.0003 \\
(0.0005)\end{array}$ & $\begin{array}{c}-.0004 \\
(0.0004)\end{array}$ \\
\hline Std Extraversion & $\begin{array}{c}0.0021^{* * *} \\
(0.0006)\end{array}$ & $\begin{array}{c}0.0011^{* *} \\
(0.0004)\end{array}$ & $\begin{array}{c}0.0003 \\
(0.0004)\end{array}$ & $\begin{array}{l}-.00008 \\
(0.0004)\end{array}$ \\
\hline Std Agreeableness & $\begin{array}{c}0.0007 \\
(0.0005)\end{array}$ & $\begin{array}{l}0.0007^{*} \\
(0.0004)\end{array}$ & $\begin{array}{c}-.0004 \\
(0.0004)\end{array}$ & $\begin{array}{c}-.0002 \\
(0.0004)\end{array}$ \\
\hline Std Neuroticism & $\begin{array}{c}-.0006 \\
(0.0005)\end{array}$ & $\begin{array}{c}0.0002 \\
(0.0004)\end{array}$ & $\begin{array}{c}-.0003 \\
(0.0004)\end{array}$ & $\begin{array}{c}3.00 \mathrm{e}-06 \\
(0.0004)\end{array}$ \\
\hline \multicolumn{5}{|l|}{ Other Personality Traits } \\
\hline Risk & & $\begin{array}{c}0.0009^{* * *} \\
(0.0002)\end{array}$ & & $\begin{array}{c}0.0007^{* * *} \\
(0.0002)\end{array}$ \\
\hline Std Internal LOC & & $\begin{array}{c}0.0012^{* * *} \\
(0.0004)\end{array}$ & & $\begin{array}{c}0.0005 \\
(0.0004)\end{array}$ \\
\hline Std External LOC & & $\begin{array}{l}-.0008^{*} \\
(0.0005)\end{array}$ & & $\begin{array}{c}-.0001 \\
(0.0004)\end{array}$ \\
\hline Std Trust & & $\begin{array}{c}0.0006 \\
(0.0004)\end{array}$ & & $\begin{array}{c}0.0006 \\
(0.0004)\end{array}$ \\
\hline \multicolumn{5}{|l|}{ School leaving degree } \\
\hline High-School & $\begin{array}{c}0.0051^{* * *} \\
(0.0019)\end{array}$ & $\begin{array}{c}0.0041^{* * *} \\
(0.0015)\end{array}$ & $\begin{array}{c}0.0032^{* *} \\
(0.0014)\end{array}$ & $\begin{array}{c}0.0028^{* *} \\
(0.0012)\end{array}$ \\
\hline Vocational training & $\begin{array}{c}0.0003 \\
(0.0014)\end{array}$ & $\begin{array}{c}0.0003 \\
(0.0011)\end{array}$ & $\begin{array}{c}-.0033^{* * *} \\
(0.0011)\end{array}$ & $\begin{array}{c}-.0026^{* *} \\
(0.0011)\end{array}$ \\
\hline Technical college & $\begin{array}{c}0.0016 \\
(0.0017)\end{array}$ & $\begin{array}{c}0.0009 \\
(0.0013)\end{array}$ & $\begin{array}{l}-.0010 \\
(0.001)\end{array}$ & $\begin{array}{c}-.0007 \\
(0.0009)\end{array}$ \\
\hline University & $\begin{array}{c}0.0057^{* *} \\
(0.0023)\end{array}$ & $\begin{array}{l}0.004^{* *} \\
(0.0017)\end{array}$ & $\begin{array}{c}0.0026 \\
(0.0016)\end{array}$ & $\begin{array}{c}0.0021 \\
(0.0014)\end{array}$ \\
\hline SE father & $\begin{array}{c}0.0026 \\
(0.0021)\end{array}$ & $\begin{array}{c}0.0015 \\
(0.0015)\end{array}$ & $\begin{array}{l}0.0035^{*} \\
(0.0018)\end{array}$ & $\begin{array}{c}0.0033^{* *} \\
(0.0016)\end{array}$ \\
\hline Capital income/1000 in EUR & $\begin{array}{c}0.0001^{* * *} \\
(0.00002)\end{array}$ & $\begin{array}{c}0.00009^{* * *} \\
(0.00002)\end{array}$ & $\begin{array}{c}1.00 \mathrm{e}-05 \\
(9.00 \mathrm{e}-06)\end{array}$ & $\begin{array}{l}1.00 \mathrm{e}-05 \\
(8.00 \mathrm{e}-06)\end{array}$ \\
\hline Not participating & $\begin{array}{c}0.0356^{* *} \\
(0.0154)\end{array}$ & $\begin{array}{c}0.0256^{* *} \\
(0.0115)\end{array}$ & $\begin{array}{c}0.0095^{* * *} \\
(0.0024)\end{array}$ & $\begin{array}{c}0.0085^{* * *} \\
(0.0023)\end{array}$ \\
\hline Unemployed & $\begin{array}{c}0.061^{* * *} \\
(0.0095)\end{array}$ & $\begin{array}{c}0.0481^{* * *} \\
(0.0081)\end{array}$ & $\begin{array}{c}0.0257^{* * *} \\
(0.0055)\end{array}$ & $\begin{array}{c}0.0218^{* * *} \\
(0.0049)\end{array}$ \\
\hline Further control variables & Yes & Yes & Yes & Yes \\
\hline \# of person-years & 27,902 & 27,902 & 32,411 & 32,411 \\
\hline Pseudo- $R^{2}$ & 0.1076 & 0.1291 & 0.0801 & 0.0909 \\
\hline log-Likelihood & $-1,782.323$ & $-1,739.36$ & $-1,681.928$ & $-1,662.095$ \\
\hline Wald $\chi^{2}$ & 421.7296 & 480.9014 & 281.6382 & 339.4749 \\
\hline
\end{tabular}


Table 3: Effect of being female on the probability of entry into self-employment

\begin{tabular}{lcccc}
\hline \hline Logit model & & & \\
\hline Effect size of being female & $-.0034^{* * *}$ & $-.0039^{* * *}$ & $-.0042^{* * *}$ & $-.0026^{* * *}$ \\
Robust std err. & $(0.001)$ & $(0.0008)$ & $(0.0007)$ & $(0.0006)$ \\
\hline Socio-demographic control variables & No & Yes & Yes & Yes \\
Big Five personality traits & No & No & Yes & Yes \\
Specific personality characteristics & No & No & No & Yes \\
$\#$ of person-years & 60,313 & 60,313 & 60,313 & 60,313 \\
Pseudo-R & 0.002 & 0.073 & 0.0864 & 0.1024 \\
log-Likelihood & $-3,825.461$ & $-3,553.139$ & $-3,501.691$ & $-3,440.464$ \\
Wald $\chi^{2}$ & 12.3299 & 520.937 & 598.0605 & 724.682 \\
\hline \hline
\end{tabular}

Note: The table shows the estimated discrete effects of being female on the probability of entry into self-employment in models with different sets of control variables. The standard errors are robust to heteroskedasticity and clustering at the individual level. Stars $(* * *)$ indicate significance at the $1 \%$ level.

Source: Authors' calculations based on the SOEP (2000-2010). 
Table 4: Detailed non-linear decomposition of the gender gap in entrepreneurial entry

\begin{tabular}{|c|c|c|c|c|c|c|}
\hline Variable & Differential & $\%$ & p-Value & Differential & $\%$ & p-Value \\
\hline Probability for Men & $0.0135^{* * *}$ & . & 0.0000 & $0.0135^{* * *}$ & . & 0.0000 \\
\hline Probability for Women & $0.0101^{* * *}$ & . & 0.0000 & $0.0101^{* * *}$ & & 0.0000 \\
\hline Raw Differential & $0.0034^{* * *}$ & 1.0000 & 0.0005 & $0.0034^{* * *}$ & 1.0000 & 0.0005 \\
\hline Explained Gap & $-0.0037^{* * *}$ & -1.0730 & 0.0000 & $-0.0016^{*}$ & -0.4588 & 0.0618 \\
\hline Big 5 & $-0.0012^{* *}$ & -0.3499 & 0.0401 & $-0.0014^{* *}$ & -0.4180 & 0.0133 \\
\hline Openness & $-0.0010^{* * *}$ & -0.2990 & 0.0000 & $-0.0009^{* * *}$ & -0.2637 & 0.0041 \\
\hline Conscientousness & 0.0001 & 0.0327 & 0.3464 & 0.0002 & 0.0655 & 0.1362 \\
\hline Extraversion & $-0.0008^{* * *}$ & -0.2244 & 0.0028 & -0.0004 & -0.1265 & 0.1032 \\
\hline Agreeablness & -0.0001 & -0.0329 & 0.7122 & -0.0003 & -0.0843 & 0.3730 \\
\hline Neuroticism & 0.0006 & 0.1738 & 0.1108 & -0.0000 & -0.0090 & 0.9384 \\
\hline Other pers. Traits & . & . & . & $0.0027^{* * *}$ & 0.7888 & 0.0077 \\
\hline Risk & . & . & . & $0.0025^{* * *}$ & 0.7236 & 0.0086 \\
\hline Internal LOC & . & . & . & 0.0001 & 0.0160 & 0.4200 \\
\hline External LOC & . & . & . & 0.0002 & 0.0479 & 0.1676 \\
\hline Trust & . & . & . & 0.0000 & 0.0013 & 0.9162 \\
\hline Education & $0.0009^{* * *}$ & 0.2580 & 0.0012 & $0.0010^{* *}$ & 0.2781 & 0.0241 \\
\hline High-School & $0.0006^{* * *}$ & 0.1651 & 0.0023 & $0.0006^{* *}$ & 0.1819 & 0.0248 \\
\hline Vocational training & -0.0001 & -0.0389 & 0.1445 & -0.0001 & -0.0376 & 0.2091 \\
\hline Technical College & -0.0000 & -0.0035 & 0.9223 & -0.0000 & -0.0026 & 0.9491 \\
\hline University & $0.0005^{* *}$ & 0.1353 & 0.0103 & $0.0005^{*}$ & 0.1364 & 0.0532 \\
\hline Year & -0.0000 & -0.0022 & 0.7045 & -0.0000 & -0.0019 & 0.7537 \\
\hline Region & 0.0000 & 0.0074 & 0.6157 & 0.0000 & 0.0116 & 0.5127 \\
\hline German & 0.0000 & 0.0012 & 0.8145 & 0.0000 & 0.0022 & 0.7238 \\
\hline Other control variables & 0.0009 & 0.2487 & 0.2547 & 0.0009 & 0.2734 & 0.3281 \\
\hline SE father & -0.0000 & -0.0046 & 0.7131 & -0.0000 & -0.0048 & 0.7134 \\
\hline Capital Income/1000 in EUR & $-0.0001^{* * *}$ & -0.0247 & 0.0062 & $-0.0001^{* *}$ & -0.0260 & 0.0294 \\
\hline Employed & $-0.0038^{* * *}$ & -1.1132 & 0.0000 & $-0.0042^{* * *}$ & -1.2313 & 0.0016 \\
\hline Not participating & -0.0004 & -0.1191 & 0.3273 & -0.0005 & -0.1576 & 0.2837 \\
\hline Unemployed & 0.0001 & 0.0267 & 0.1909 & 0.0001 & 0.0288 & 0.2240 \\
\hline Unexplained Gap & $0.0071^{* * *}$ & 2.0730 & 0.0000 & $0.0050^{* * *}$ & 1.4588 & 0.0001 \\
\hline Big 5 & -0.0001 & -0.0296 & 0.2890 & -0.0002 & -0.0487 & 0.2058 \\
\hline Openness & 0.0000 & 0.0049 & 0.6614 & 0.0000 & 0.0011 & 0.9285 \\
\hline Conscientousness & -0.0000 & -0.0031 & 0.3971 & -0.0000 & -0.0022 & 0.6431 \\
\hline Extraversion & -0.0000 & -0.0132 & 0.3553 & -0.0001 & -0.0158 & 0.3690 \\
\hline Agreeablness & 0.0000 & 0.0007 & 0.9561 & 0.0000 & 0.0002 & 0.9920 \\
\hline Neuroticism & -0.0001 & -0.0190 & 0.2013 & -0.0001 & -0.0319 & 0.1298 \\
\hline Other pers. Traits & . & . & . & -0.0096 & -2.8096 & 0.1418 \\
\hline Risk & . & . & . & -0.0096 & -2.8128 & 0.1415 \\
\hline Internal LOC & . & . & . & 0.0000 & 0.0015 & 0.8135 \\
\hline External LOC & . & 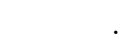 & 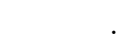 & 0.0000 & 0.0015 & 0.8381 \\
\hline Trust & & & & 0.0000 & 0.0000 & 0.9269 \\
\hline Education & $0.0071^{* *}$ & 2.0688 & 0.0420 & $0.0075^{*}$ & 2.1934 & 0.0983 \\
\hline High-School & 0.0005 & 0.1457 & 0.6575 & 0.0007 & 0.2038 & 0.6024 \\
\hline Vocational training & $0.0045^{* *}$ & 1.3003 & 0.0266 & $0.0047^{*}$ & 1.3816 & 0.0673 \\
\hline Technical College & 0.0013 & 0.3911 & 0.1938 & 0.0012 & 0.3521 & 0.3282 \\
\hline University & 0.0008 & 0.2316 & 0.4348 & 0.0009 & 0.2559 & 0.4619 \\
\hline Year & 0.0000 & 0.0125 & 0.6686 & 0.0000 & 0.0115 & 0.7340 \\
\hline Region & 0.0037 & 1.0709 & 0.1111 & 0.0045 & 1.3166 & 0.1324 \\
\hline German & -0.0033 & -0.9706 & 0.5952 & -0.0025 & -0.7576 & 0.7300 \\
\hline Other control variables & -0.0312 & -9.1161 & 0.3394 & -0.0226 & -6.6032 & 0.5445 \\
\hline SE father & -0.0002 & -0.0548 & 0.5336 & -0.0003 & -0.0932 & 0.3605 \\
\hline Capital Income/1000 in EUR & $0.0005^{* * *}$ & 0.1370 & 0.0007 & $0.0005^{* *}$ & 0.1495 & 0.0148 \\
\hline Employed & $-0.0058^{*}$ & -1.7083 & 0.0616 & -0.0066 & -1.9241 & 0.1182 \\
\hline Not participating & 0.0000 & 0.0118 & 0.8564 & 0.0000 & 0.0129 & 0.8636 \\
\hline Unemployed & 0.0002 & 0.0467 & 0.4408 & 0.0003 & 0.0740 & 0.3290 \\
\hline Constant & 0.0330 & 9.6342 & 0.3102 & 0.0314 & 9.1799 & 0.3998 \\
\hline \# of person-years & 60,313 & & & 60,313 & & \\
\hline
\end{tabular}

Note: The p-Value refers to a test of significance of the differential. Other control variables are age, age squared, years of work experience, years of unemployment difference, disabled, number of children, martial status; Year and Region include year and region dummies. $* * * / * / *$ indicate significance at the $1 / 5 / 10 \%$ levels.

Source: Authors' calculations based on the SOEP (2000-2010). 


\section{Appendix A}

Table A.1: Person-year observations entering and not entering into self-employment

\begin{tabular}{lcccc}
\hline \hline & No entry & Entry & Total & Entry rate \\
\hline Men & 27,525 & 377 & 27,902 & 0.0135 \\
Wage employed & 25,607 & 265 & 25,872 & 0.0102 \\
Unemployed & 1,647 & 100 & 1,747 & 0.0572 \\
Not participating & 271 & 12 & 283 & 0.0424 \\
Women & 32,084 & 327 & 32,411 & 0.0101 \\
Wage employed & 24,188 & 167 & 24,355 & 0.0069 \\
Unemployed & 1,823 & 54 & 1,877 & 0.0288 \\
Not participating & 6,073 & 106 & 6,179 & 0.0172 \\
Total (men and women) & 59,609 & 704 & 60,313 & 0.0117 \\
\hline \hline
\end{tabular}

Source: Authors' calculations based on the SOEP (2000-2010). 
Table A.2: Inventories used to measure the personality traits

\begin{tabular}{|c|c|}
\hline Personality trait & Questionnaire wording \\
\hline Big Five Model & $\begin{array}{l}\text { Scale: } 1 \text { ("does not apply to me at all") to } 7 \text { ("applies to me perfectly") } \\
\text { I see myself as someone who ... }\end{array}$ \\
\hline Openness to experience & is original, comes up with new ideas \\
\hline Openness to experience & values artistic experiences \\
\hline Openness to experience & has an active imagination \\
\hline Conscientiousness & does a thorough job \\
\hline Conscientiousness & does things effectively and efficiently \\
\hline Conscientiousness (inverted) & tends to be lazy \\
\hline Extraversion & is communicative, talkative \\
\hline Extraversion & is outgoing, sociable \\
\hline Extraversion (inverted) & is reserved \\
\hline Agreeableness & has a forgiving nature \\
\hline Agreeableness & is considerate and kind to others \\
\hline Agreeableness (inverted) & is sometimes somewhat rude to others \\
\hline Neuroticism & worries a lot \\
\hline Neuroticism & gets nervous easily \\
\hline Neuroticism (inverted) & is relaxed, handles stress well \\
\hline Locus of control & Scale: 1 ("disagree completely") to 7 ("agree completely") \\
\hline Internal locus & How my life goes depends on me \\
\hline Internal locus & One has to work hard in order to succeed \\
\hline Internal locus (inverted) & If I run up against difficulties in life, I often doubt my own abilities \\
\hline Internal locus (not used) & $\begin{array}{l}\text { If a person is socially or politically active, he/she can have an effect on } \\
\text { social conditions }\end{array}$ \\
\hline External locus & Compared to other people, I have not achieved what I deserve \\
\hline External locus & What a person achieves in life is above all a question of fate or luck \\
\hline External locus & $\begin{array}{l}\text { I frequently have the experience that other people have a controlling } \\
\text { influence over my life }\end{array}$ \\
\hline External locus & $\begin{array}{l}\text { The opportunities that I have in life are determined by the social con- } \\
\text { ditions }\end{array}$ \\
\hline External locus & Inborn abilities are more important than any efforts one can make \\
\hline External locus & I have little control over the things that happen in my life \\
\hline Trust & Scale: 1 ("totally agree") to 4 ("totally disagree") \\
\hline Trust (inverted) & On the whole one can trust people \\
\hline Trust & Nowadays one can't rely on anyone \\
\hline Trust & $\begin{array}{l}\text { If one is dealing with strangers, it is better to be careful before one can } \\
\text { trust them }\end{array}$ \\
\hline \multirow[t]{2}{*}{ Risk tolerance } & $\begin{array}{l}\text { Scale: } 0 \text { ("fully unwilling to take risks") to } 10 \text { ("fully willing to take } \\
\text { risk") }\end{array}$ \\
\hline & $\begin{array}{l}\text { Are you generally a person who is fully prepared to take risks or do you } \\
\text { try to avoid taking risks? }\end{array}$ \\
\hline
\end{tabular}

Notes: The items on the Big Five factors were included in the survey waves 2005 and 2009 of the SOEP; those on locus of control in 2005; those on trust in 2003 and 2008; on the willingness to take risks in 2004, 2006, 2008, and 2009

Source: Adapted from Caliendo et al. (2014). 
Table A.3: Industry of self-employment by gender

\begin{tabular}{lrrr}
\hline \hline \multirow{2}{*}{ Industry } & \multicolumn{3}{c}{ Entry sample } \\
\hline Manufacturing & Men & Women & p-Value \\
Agriculture, forestry & 0.0690 & 0.0275 & 0.0116 \\
Mining/ quarrying, energy/ water supply & 0.0080 & 0.0000 & 0.1063 \\
Chemicals, pulp and paper industry & 0.0053 & 0.0031 & 0.6486 \\
Construction and nonmetalic mineral processing & 0.0186 & 0.0183 & 0.9829 \\
Iron and steel industry & 0.1300 & 0.0214 & 0.0000 \\
Textile and apparel industry & 0.0239 & 0.0061 & 0.0583 \\
Wholesale and retail trade & 0.0027 & 0.0183 & 0.0364 \\
Transport and communication & 0.1379 & 0.1437 & 0.8256 \\
Public and social service activities & 0.0345 & 0.0245 & 0.4365 \\
Financial intermediation and private services & 0.1326 & 0.2446 & 0.0001 \\
Not categorized & 0.2865 & 0.1957 & 0.0051 \\
\# of person-years & 0.1512 & 0.2966 & 0.0000 \\
\hline \hline
\end{tabular}

Notes: The p-values refer to t-tests of equal means by gender.

Source: Authors' calculations based on the SOEP (2000-2010). 
Table A.4: Logit estimation of the probability of entry into selfemployment: Coefficients

\begin{tabular}{|c|c|c|c|c|c|c|}
\hline & \multicolumn{2}{|c|}{ Full sample } & \multicolumn{2}{|c|}{ Men } & \multicolumn{2}{|c|}{ Women } \\
\hline Female & $\begin{array}{c}-.5529^{* * *} \\
(0.0993)\end{array}$ & $\begin{array}{c}-.4196^{* * *} \\
(0.1023)\end{array}$ & & & & \\
\hline \multicolumn{7}{|l|}{ Big 5} \\
\hline Std Openness & $\begin{array}{c}0.3219^{* * *} \\
(0.0462)\end{array}$ & $\begin{array}{c}0.2593^{* * *} \\
(0.0458)\end{array}$ & $\begin{array}{c}0.2279^{* * *} \\
(0.0636)\end{array}$ & $\begin{array}{c}0.1778^{* * *} \\
(0.0627)\end{array}$ & $\begin{array}{c}0.4169^{* * *} \\
(0.0677)\end{array}$ & $\begin{array}{c}0.351^{* * *} \\
(0.0679)\end{array}$ \\
\hline Std Conscientiousness & $\begin{array}{c}-.0467 \\
(0.0483)\end{array}$ & $\begin{array}{l}-.0856^{*} \\
(0.0482)\end{array}$ & $\begin{array}{c}-.0342 \\
(0.0664)\end{array}$ & $\begin{array}{c}-.0926 \\
(0.0674)\end{array}$ & $\begin{array}{c}-.0494 \\
(0.0701)\end{array}$ & $\begin{array}{c}-.0699 \\
(0.0688)\end{array}$ \\
\hline Std Extraversion & $\begin{array}{c}0.1466^{* * *} \\
(0.0477)\end{array}$ & $\begin{array}{c}0.0755 \\
(0.0481)\end{array}$ & $\begin{array}{c}0.2486^{* * *} \\
(0.068)\end{array}$ & $\begin{array}{c}0.1731^{* *} \\
(0.0683)\end{array}$ & $\begin{array}{c}0.0513 \\
(0.0666)\end{array}$ & $\begin{array}{l}-.0135 \\
(0.067)\end{array}$ \\
\hline Std Agreeableness & $\begin{array}{c}0.0166 \\
(0.0452)\end{array}$ & $\begin{array}{c}0.0388 \\
(0.0448)\end{array}$ & $\begin{array}{c}0.0853 \\
(0.0623)\end{array}$ & $\begin{array}{c}0.1062^{*} \\
(0.06)\end{array}$ & $\begin{array}{l}-.0641 \\
(0.066)\end{array}$ & $\begin{array}{l}-.0397 \\
(0.0667)\end{array}$ \\
\hline Std Neuroticism & $\begin{array}{l}-.0745^{*} \\
(0.0438)\end{array}$ & $\begin{array}{c}0.0035 \\
(0.0457)\end{array}$ & $\begin{array}{c}-.0752 \\
(0.0633)\end{array}$ & $\begin{array}{c}0.0339 \\
(0.0648)\end{array}$ & $\begin{array}{l}-.0517 \\
(0.0614)\end{array}$ & $\begin{array}{c}0.0004 \\
(0.0648)\end{array}$ \\
\hline \multicolumn{7}{|l|}{ Other Personality Traits } \\
\hline Risk & & $\begin{array}{c}-.1494^{* *} \\
(0.0678)\end{array}$ & & $\begin{array}{c}-.2675^{* * *} \\
(0.1035)\end{array}$ & & $\begin{array}{c}-.0353 \\
(0.0925)\end{array}$ \\
\hline Risk sq. & & $\begin{array}{c}0.0307^{* * *} \\
(0.0064)\end{array}$ & & $\begin{array}{c}0.0408^{* * *} \\
(0.0093)\end{array}$ & & $\begin{array}{c}0.0193^{* *} \\
(0.0094)\end{array}$ \\
\hline Std Internal LOC & & $\begin{array}{c}0.1239^{* * *} \\
(0.0466)\end{array}$ & & $\begin{array}{c}0.1856^{* * *} \\
(0.0679)\end{array}$ & & $\begin{array}{c}0.0831 \\
(0.0643)\end{array}$ \\
\hline Std External LOC & & $\begin{array}{c}-.0733 \\
(0.0471)\end{array}$ & & $\begin{array}{l}-.1243^{*} \\
(0.0697)\end{array}$ & & $\begin{array}{l}-.0202 \\
(0.0632)\end{array}$ \\
\hline Std Trust & & $\begin{array}{c}0.0927^{* *} \\
(0.0453)\end{array}$ & & $\begin{array}{c}0.0979 \\
(0.0649)\end{array}$ & & $\begin{array}{c}0.0944 \\
(0.0628)\end{array}$ \\
\hline \multicolumn{7}{|l|}{ School leaving degree } \\
\hline High-School & $\begin{array}{c}0.4788^{* * *} \\
(0.1201)\end{array}$ & $\begin{array}{c}0.4819^{* * *} \\
(0.1202)\end{array}$ & $\begin{array}{c}0.5362^{* * *} \\
\quad(0.18)\end{array}$ & $\begin{array}{c}0.5567^{* * *} \\
(0.1856)\end{array}$ & $\begin{array}{c}0.4242^{* *} \\
(0.1681)\end{array}$ & $\begin{array}{c}0.4208^{* *} \\
(0.1658)\end{array}$ \\
\hline Vocational training & $\begin{array}{c}-.1968^{*} \\
(0.118)\end{array}$ & $\begin{array}{c}-.1741 \\
(0.1188)\end{array}$ & $\begin{array}{c}0.0406 \\
(0.1648)\end{array}$ & $\begin{array}{c}0.0438 \\
(0.1634)\end{array}$ & $\begin{array}{c}-.4889^{* * *} \\
(0.1673)\end{array}$ & $\begin{array}{c}-.4485^{* * *} \\
(0.1722)\end{array}$ \\
\hline Technical college & $\begin{array}{c}0.012 \\
(0.1227)\end{array}$ & $\begin{array}{c}0.0079 \\
(0.1238)\end{array}$ & $\begin{array}{c}0.1764 \\
(0.1844)\end{array}$ & $\begin{array}{l}0.1329 \\
(0.186)\end{array}$ & $\begin{array}{l}-.1490 \\
(0.163)\end{array}$ & $\begin{array}{c}-.1226 \\
(0.1664)\end{array}$ \\
\hline University & $\begin{array}{c}0.4568^{* * *} \\
(0.1343)\end{array}$ & $\begin{array}{c}0.4206^{* * *} \\
(0.1351)\end{array}$ & $\begin{array}{c}0.5719^{* * *} \\
(0.1976)\end{array}$ & $\begin{array}{c}0.5369^{* * *} \\
(0.1963)\end{array}$ & $\begin{array}{l}0.3532^{*} \\
(0.1938)\end{array}$ & $\begin{array}{c}0.3269^{*} \\
(0.196)\end{array}$ \\
\hline Age & $\begin{array}{c}0.1336^{* * *} \\
(0.0504)\end{array}$ & $\begin{array}{c}0.1427^{* * *} \\
(0.0501)\end{array}$ & $\begin{array}{c}0.0972 \\
(0.0676)\end{array}$ & $\begin{array}{c}0.1238^{*} \\
(0.068)\end{array}$ & $\begin{array}{c}0.1675^{* *} \\
(0.0782)\end{array}$ & $\begin{array}{c}0.1649^{* *} \\
(0.077)\end{array}$ \\
\hline Age sq. & $\begin{array}{c}-.0019^{* * *} \\
(0.0006)\end{array}$ & $\begin{array}{c}-.0020^{* * *} \\
(0.0006)\end{array}$ & $\begin{array}{l}-.0016^{*} \\
(0.0008)\end{array}$ & $\begin{array}{c}-.0019^{* *} \\
(0.0008)\end{array}$ & $\begin{array}{c}-.0023^{* *} \\
(0.0009)\end{array}$ & $\begin{array}{c}-.0022^{* *} \\
(0.0009)\end{array}$ \\
\hline Yrs work experience/10 & $\begin{array}{c}0.0807 \\
(0.0955)\end{array}$ & $\begin{array}{c}0.0827 \\
(0.0956)\end{array}$ & $\begin{array}{c}0.142 \\
(0.1898)\end{array}$ & $\begin{array}{c}0.1513 \\
(0.1914)\end{array}$ & $\begin{array}{c}0.0957 \\
(0.1221)\end{array}$ & $\begin{array}{l}0.0893 \\
(0.123)\end{array}$ \\
\hline Yrs unempl. experience/10 & $\begin{array}{l}-.5150^{*} \\
(0.2969)\end{array}$ & $\begin{array}{l}-.4046 \\
(0.2956)\end{array}$ & $\begin{array}{c}-1.1420^{* *} \\
(0.5278)\end{array}$ & $\begin{array}{l}-.8915^{*} \\
(0.5157)\end{array}$ & $\begin{array}{l}0.1615 \\
(0.347)\end{array}$ & $\begin{array}{c}0.2099 \\
(0.3544)\end{array}$ \\
\hline Disabled & $\begin{array}{l}-.1651 \\
(0.213)\end{array}$ & $\begin{array}{c}-.1393 \\
(0.2137)\end{array}$ & $\begin{array}{l}-.0940 \\
(0.2601)\end{array}$ & $\begin{array}{c}-.0654 \\
(0.2589)\end{array}$ & $\begin{array}{c}-.3572 \\
(0.3676)\end{array}$ & $\begin{array}{l}-.3310 \\
(0.367)\end{array}$ \\
\hline German & $\begin{array}{c}-.0485 \\
(0.1999)\end{array}$ & $\begin{array}{c}-.0777 \\
(0.2006)\end{array}$ & $\begin{array}{c}-.1599 \\
(0.2642)\end{array}$ & $\begin{array}{c}-.1444 \\
(0.2652)\end{array}$ & $\begin{array}{c}0.0527 \\
(0.2979)\end{array}$ & $\begin{array}{c}-.0046 \\
(0.3001)\end{array}$ \\
\hline SE father & $\begin{array}{c}0.3752^{* * *} \\
(0.1326)\end{array}$ & $\begin{array}{c}0.3579^{* * *} \\
(0.1326)\end{array}$ & $\begin{array}{l}0.2683 \\
(0.192)\end{array}$ & $\begin{array}{c}0.2143 \\
(0.1917)\end{array}$ & $\begin{array}{c}0.4356^{* *} \\
(0.1862)\end{array}$ & $\begin{array}{c}0.4625^{* *} \\
(0.1833)\end{array}$ \\
\hline \# of children & $\begin{array}{l}0.0445 \\
(0.049)\end{array}$ & $\begin{array}{c}0.0355 \\
(0.0488)\end{array}$ & $\begin{array}{l}0.0665 \\
(0.072)\end{array}$ & $\begin{array}{c}0.0562 \\
(0.0724)\end{array}$ & $\begin{array}{c}0.0525 \\
(0.0685)\end{array}$ & $\begin{array}{c}0.0449 \\
(0.0681)\end{array}$ \\
\hline Married & $\begin{array}{c}-.1287 \\
(0.1116)\end{array}$ & $\begin{array}{c}-.0998 \\
(0.1135)\end{array}$ & $\begin{array}{l}-.2954^{*} \\
(0.1585)\end{array}$ & $\begin{array}{c}-.3206^{* *} \\
(0.1623)\end{array}$ & $\begin{array}{c}0.0867 \\
(0.1694)\end{array}$ & $\begin{array}{c}0.1562 \\
(0.1702)\end{array}$ \\
\hline Divorced & $\begin{array}{c}-.2101 \\
(0.1839)\end{array}$ & $\begin{array}{c}-.2549 \\
(0.1872)\end{array}$ & $\begin{array}{l}-.2250 \\
(0.2511)\end{array}$ & $\begin{array}{l}-.3246 \\
(0.259)\end{array}$ & $\begin{array}{c}-.1977 \\
(0.2728)\end{array}$ & $\begin{array}{c}-.1915 \\
(0.2736)\end{array}$ \\
\hline
\end{tabular}

(Table continued on next page) 
(Table continued)

\begin{tabular}{lcccccc}
\hline \hline & \multicolumn{2}{c}{ Full sample } & \multicolumn{2}{c}{ Men } & \multicolumn{2}{c}{ Women } \\
\hline East Germany & 0.0194 & 0.0378 & 0.0626 & 0.0932 & -.0441 & -.0440 \\
& $(0.1165)$ & $(0.117)$ & $(0.1593)$ & $(0.158)$ & $(0.1855)$ & $(0.1856)$ \\
South Germany & 0.0216 & 0.0571 & -.0709 & -.0211 & 0.165 & 0.1864 \\
& $(0.1101)$ & $(0.1111)$ & $(0.1546)$ & $(0.1559)$ & $(0.1571)$ & $(0.1582)$ \\
North Germany & -.1506 & -.1489 & -.2366 & -.2162 & -.0393 & -.0402 \\
& $(0.1595)$ & $(0.1613)$ & $(0.2317)$ & $(0.234)$ & $(0.2199)$ & $(0.2211)$ \\
City States & -.3448 & -.4119 & -.9557 & $-1.0676^{*}$ & 0.2394 & 0.2092 \\
& $(0.3565)$ & $(0.3646)$ & $(0.5857)$ & $(0.5931)$ & $(0.4211)$ & $(0.4375)$ \\
Capital income/1000 in EUR & $0.0052^{* * *}$ & $0.005^{* * *}$ & $0.0145^{* * *}$ & $0.0138^{* * *}$ & 0.0021 & 0.002 \\
& $(0.0011)$ & $(0.0011)$ & $(0.0025)$ & $(0.0026)$ & $(0.0013)$ & $(0.0014)$ \\
Not participating & $1.1864^{* * *}$ & $1.2207^{* * *}$ & $1.6852^{* * *}$ & $1.6317^{* * *}$ & $1.0097^{* * *}$ & $1.0225^{* * *}$ \\
& $(0.1649)$ & $(0.1651)$ & $(0.3732)$ & $(0.3765)$ & $(0.1938)$ & $(0.1948)$ \\
Unemployed & $2.0370^{* * *}$ & $2.0353^{* * *}$ & $2.2771^{* * *}$ & $2.3013^{* * *}$ & $1.6826^{* * *}$ & $1.6471^{* * *}$ \\
& $(0.1286)$ & $(0.1291)$ & $(0.1751)$ & $(0.1767)$ & $(0.2013)$ & $(0.2016)$ \\
Const. & $-7.2125^{* * *}$ & $-7.5586^{* * *}$ & $-6.5589^{* * *}$ & $-7.0250^{* * *}$ & $-8.3630^{* * *}$ & $-8.5454^{* * *}$ \\
& $(0.9853)$ & $(0.988)$ & $(1.3549)$ & $(1.3631)$ & $(1.5184)$ & $(1.5087)$ \\
\hline Year-Dummies & Yes & Yes & Yes & Yes & Yes & Yes \\
$\#$ of person-years & 60,313 & 60,313 & 27,902 & 27,902 & 32,411 & 32,411 \\
Pseudo-R & 0.0864 & 0.1024 & 0.1076 & 0.1291 & 0.0801 & 0.0909 \\
log-Likelihood & $-3,501.691$ & $-3,440.464$ & $-1,782.323$ & $-1,739.36$ & $-1,681.928$ & $-1,662.095$ \\
Wald $\chi^{2}$ & 598.0605 & 724.682 & 421.7296 & 480.9014 & 281.6382 & 339.4749 \\
\hline \hline
\end{tabular}

Notes: Estimates are controlled for year effects. Cluster and heteroskedasticity robust standard errors in parentheses. $* * * / * * / *$ indicate significance at the $1 / 5 / 10 \%$ levels, respectively.

Detailed information on all variables are provided in Table A.5.

Source: Authors' calculations based on the SOEP (2000-2010). 
Table A.5: Description of control variables

\begin{tabular}{ll}
\hline \hline Variable & Definition \\
\hline Female & Dummy for females \\
High School & Dummy for individuals who finished higher secondary school with a uni- \\
& versity entrance qualification \\
Vocational Training & Dummy for individuals who finished an apprenticeship \\
Technical College & Dummy for individuals who finished a higher technical college, a health \\
& care school, or civil service training \\
University & Dummy for individuals who have a university degree \\
Age & Age of individual \\
Yrs work experience/ & Years of full time work experience prior to the year of observation, divided \\
10 & by 10 \\
Yrs unempl. experi- & Years of unemployment experience prior to the year of observation, divided \\
ence/ 10 & by 10 \\
Disabled & Dummy for physically challenged individuals \\
German & Dummy for German nationality \\
SE father & Dummy for indiv. whose father was self-empl. when the respondents were \\
& 15 years old \\
\# of children & Number of children under 17 in the household \\
Married & Dummy for married and not separated individuals. Omitted category for \\
& marital status is "single" /"widowed" \\
Divorced & Dummy for divorced individuals. Omitted category for marital status is \\
& "single" / widowed" \\
East & Dummy for individuals living in the area of former East Germany or Berlin \\
South & Dummy for individuals living in Baden Wuerttemberg or Bavaria \\
North & Dummy for individuals living in Schleswig Holstein or Lower Saxony \\
City States & Dummy for individuals living in Bremen or Hamburg \\
Capital income/ 1000 & Real income from interests, dividends, and house rents in 1000 Euro in \\
in EUR & prices of 2005 \\
Not participating & Dummy for individuals not participating in the labor market \\
Unemployed & Dummy for individuals who are unemployed \\
x sq. & Square of variable x \\
\hline \hline &
\end{tabular}

Notes: Dummy variables equal 1 if condition holds and 0 otherwise.

1 Uses information from the lifetime employment history in the SOEP.

2 Some respondents report the exact amount of their financial income, while others just indicate a range. For the latter respondents, we impute the mean income of those who actually give the exact amount within this range. 


\section{Appendix B}

Our logit model of the probability of entry into self-employment can be written as:

$$
Y=F(X \beta)
$$

where $Y$ is the vector of predicted entry probabilities, $X$ the matrix of independent variables, $\beta$ the coefficient vector, and $F$ the cumulative logistic distribution function. A non-linear decomposition of the mean difference in entrepreneurial entry by gender can be written as:

$$
\bar{Y}_{M}-\bar{Y}_{F}=\left[\overline{F\left(X_{M} \beta_{M}\right)}-\overline{F\left(X_{F} \beta_{M}\right)}\right]+\left[\overline{F\left(X_{F} \beta_{M}\right)}-\overline{F\left(X_{F} \beta_{F}\right)}\right]
$$

where index $M$ stands for the male subsample and index $F$ for the female subsample. In equation B. 2 the first summand is the contribution of the distribution of the variables to the overall gender gap, i.e. the explained part, whereas the second summand is the contribution of differences in the coefficients (including the constant), i.e. the unexplained part. ${ }^{29}$ Following the approach of Yun (2004), for a detailed decomposition which assesses the contributions of each single variable (or group of variables) separately in this non-linear setting, both for the explained and unexplained gaps, two approximations are necessary. First, we consider predictions at the mean values of the explanatory variables:

$$
\bar{Y}_{M}-\bar{Y}_{F}=\left[F\left(\bar{X}_{M} \beta_{M}\right)-F\left(\bar{X}_{F} \beta_{M}\right)\right]+\left[F\left(\bar{X}_{F} \beta_{M}\right)-F\left(\bar{X}_{F} \beta_{F}\right)\right]+R_{A}
$$

where

$$
\begin{aligned}
R_{A} & =\left[\overline{F\left(X_{M} \beta_{M}\right)}-\overline{F\left(X_{F} \beta_{M}\right)}\right]+\left[\overline{F\left(X_{F} \beta_{M}\right)}-\overline{F\left(X_{F} \beta_{F}\right)}\right] \\
& -\left[F\left(\bar{X}_{M} \beta_{M}\right)-F\left(\bar{X}_{F} \beta_{M}\right)\right]+\left[F\left(\bar{X}_{F} \beta_{M}\right)-F\left(\bar{X}_{F} \beta_{F}\right)\right] .
\end{aligned}
$$

Second, a first order Taylor expansion around the mean characteristics is used. Hence, we can rewrite equation B.3 as follows:

$$
\begin{aligned}
\bar{Y}_{M}-\bar{Y}_{F} & =\left[\left(\bar{X}_{M}-\bar{X}_{F}\right) \beta_{M}\right] f\left(\bar{X}_{M} \beta_{M}\right) \\
& +\bar{X}_{F}\left(\beta_{M}-\beta_{F}\right) f\left(\bar{X}_{F} \beta_{F}\right)+R_{A}+R_{T}
\end{aligned}
$$

In this equation $f(\cdot)$ is the first order derivative of $F(\cdot)$, and

$$
\begin{aligned}
R_{T} & =\left[F\left(\bar{X}_{M} \beta_{M}\right)-F\left(\bar{X}_{F} \beta_{M}\right)\right]+\left[F\left(\bar{X}_{F} \beta_{M}\right)-F\left(\bar{X}_{F} \beta_{F}\right)\right] \\
& -\left[\left(\bar{X}_{M}-\bar{X}_{F}\right) \beta_{M}\right] f\left(\bar{X}_{M} \beta_{M}\right)-\bar{X}_{F}\left(\beta_{M}-\beta_{F}\right) f\left(\bar{X}_{F} \beta_{F}\right)
\end{aligned}
$$

Using B.5, a detailed decomposition of equation B.2 can be written as

$$
\bar{Y}_{M}-\bar{Y}_{F}=\sum_{i=1}^{K} W_{\Delta X}^{i}\left[\overline{F\left(X_{M} \beta_{M}\right)}-\overline{F\left(X_{F} \beta_{M}\right)}\right]+\sum_{i=1}^{K} W_{\Delta \beta}^{i}\left[\overline{F\left(X_{F} \beta_{M}\right)}-\overline{F\left(X_{F} \beta_{F}\right)}\right] \text { B }
$$

i.e., the detailed decomposition includes weights for the contributions of the characteristics

\footnotetext{
${ }^{29}$ More precisely, as mentioned in Section 3.4, we use the coefficient estimates from a pooled estimation for the decomposition of the contributions of the endowements to the gap; see Jann (2008) for the technical details.
} 
$\left(W_{\Delta X}^{i}\right)$ and for the contributions of the coefficients $\left(W_{\Delta \beta}^{i}\right)$, with

$$
W_{\Delta X}^{i}=\frac{\left(\bar{X}_{M}^{i}-\bar{X}_{F}^{i}\right) \beta_{M}^{i}}{\left(\bar{X}_{M}-\bar{X}_{F}\right) \beta_{M}} \quad \text { and } \quad W_{\Delta \beta}^{i}=\frac{\bar{X}_{F}^{i}\left(\beta_{M}^{i}-\beta_{F}^{i}\right)}{\bar{X}_{F}\left(\beta_{M}-\beta_{F}\right)}
$$

for variable $i$ in the set of $K$ explanatory variables (Yun, 2004). 